\title{
INTERCOMPANY ACCOUNTING UNDER THE NEW CONSOLIDATED RETURN REGULATIONS
}

Section 1501 of the Internal Revenue Code of 1954 permits an affiliated group of corporations to file a consolidated income tax return. The requirement for affiliation is that at least 80 per cent of the voting and 80 per cent of the non-voting stock of each corporation be owned by one or more of the other corporations, and that the common parent own these percentages of the stock of at least one of the other corporations. ${ }^{1}$ Underlying the consolidated return is the theory that what is in reality an economic unit should be treated as such. For example, if a parent corporation has a profit and its wholly-owned subsidiary has a loss, the economic unit actually is in a better position for the tax period by only the net amount of the profit and loss. In recognition of this fact, the consolidated return taxes only that net amount. Congress felt that there was no reason to distinguish, for tax purposes, between a corporation with many divisions and many corporations under common control. ${ }^{2}$

The regulations in this area have special weight and importance. The rules regarding taxation of the group were felt to be too complex for legislative treatment and, therefore, the Secretary of the Treasury or his delegate is authorized to prescribe legislative regulations. ${ }^{3}$ The parties must acquiesce in these regulations as a condition to filing a

1 INT. REV. CoDE of 1954, \$1504(a). The ownership requirement does not include stock limited and preferred as to dividends. INT. REv. CODE of 1954, §1501. Brother-sister corporations were permitted to file consolidated returns until 1928. See, e.g., Revenue Act of 1926, ch. 27, $\$ 240$ (d) (2), 44 Stat. 46.

2 See, e.g., S. REP. No. 960, 70th Cong., 1st Sess. 14 (1928) ; S. Rep. No. 558, 73d Cong., 2d Sess. 18 (1934); M. Moonitz, The Entity Theory of Consolmated Statearents (1944). But see Salem, Advantages and Disadvantages of Filing Consolidated Returns-A Fresh Look, 45 TAXES 141 (1967). Salem disputes the entity theory of consolidated returns on the ground that there have always been differences between the treatment of a branch and the treatment of a subsidiary under the regulations. This may, however, only expose a defect in the regulations. The legislative history, supra, is replete with unequivocal language saying that there should be no distinction. In addition, there seems to be no policy justification for different treatment, especially in light of the elimination of the two per cent surtax which was previously required for filing a consolidated return. See Revenue Act of 1964, Pub. L. No. 88-272, $\$ 234(\mathrm{a}), 78$ Stat. 19 (codified in scattered sections of 26 U.S.C.), annending INT. REv. CODE of 1954, \$1503(a) (eliminating the surtax with respect to taxable years beginning after December 31, 1963).

Continuing minority interest in the subsidiary may create a need, in some instances, to diverge from branch-type treatment. Such a minority, limited to an interest in the subsidiary, could not occur if there were an actual consolidation. However, this does not vitiate the entity theory as a point of reference to be departed from only for good reason. It also does not contravene the legislative intent which speaks to the basic situation where the two forms are both conceptually and in substance identical.

3 INT. REv. CODE of $1954, \S 1502$. 
consolidated return. ${ }^{4}$ As a result, the Commissioner has very broad discretion in promulgating the consolidated return regulations.

During the last few years, a complete revision of these regulations has been in progress as a result of a long-felt need for simplification and for solutions to certain pressing problems. One of the most significant problems was that of accounting for intercompany transactions and stockholdings. ${ }^{5}$ After being reworked a number of times following publication as proposals, the regulations were adopted in final form in December, 1966. ${ }^{6}$ The purpose of this Comment is to examine the problems involved and to evaluate the solutions offered by the new regulations. ${ }^{7}$

\section{The Problems Arising Under the Old Regulations}

The basic theory of the old regulations was to treat intercompany stockholdings as they would be treated if no consolidated return were filed, ${ }^{8}$ and to eliminate income or loss on intercompany transactions, ${ }^{9}$ on the theory that no gain had been realized to the affiliated group.

\section{Acquisition of Stock}

Under this system, if Corporation $P$ purchased all the stock of Corporation $S$ for $\$ 100$, the basis of the stock in $P$ 's hands would be $\$ 100$ and the basis of the assets would remain the same as before the purchase. ${ }^{10}$ Thus, if the assets had a basis of $\$ 50$ in the hands of $S$, the basis would remain $\$ 50$, although the parent had paid $\$ 100$ for the stock. If the assets had a basis of $\$ 200$, the basis remained $\$ 200$. In the latter case, however, this would mean that the parent, on the (1928).

4 INr. Rev. Code of 1954, § 1501. See S. Rep. No. 960, 70th Cong., 1st Sess. 15

5 Salem, The Consolidated Return Regulation Revision: Its Genesis and Objectives, 17 TAx EXecutrve 163 (1965); Note, 78 HARv. I. REv. 1415 (1965). Remarks of Assistant Secretary of the Treasury Stanley R. Surrey, Harvard LAw ReCoRD, Dec. 10, 1964, at 13, col. 2.

6 The regulations were submitted in proposed form in September of 1965, 30 Fed. Reg. 1256412617 (1965) [hereinafter cited as Proposed Treas. Reg. (I)]. A majority were adopted with some modification in September, 1966, 31 Fed. Reg. 11794 11844 (1966) [hereinafter cited as Proposed Treas. Reg. (II)]. Others were withdrawn, 31 Fed. Reg. 11845 (1966), and new proposals offered, 31 Fed. Reg. $11845-11850$ (1966). These proposals were finally adopted, again with modification, in December, 1966, 31 Fed. Reg. 16694-16700 (1966).

7 This Comment will not consider the new regulations concerning the carryover of losses realized prior to affiliation, Treas. Reg. $\$ 1.1502-21$ (1966), or the special adjustment for intercompany transfers of inventory, Treas. Reg. $\$ 1.1502-18$ (1966). For a discussion of these areas, see Salem, How to use net operating losses effectively and the new consolidated return regulations, $26 \mathrm{~J}$. TAXATroN 270 (1967); Cohen, The new consolidated return regs: a bird's-eye view of the extensive changes, $24 \mathrm{~J}$. TAxation 82, 84 (1966).

8 See Treas. Reg. $\$ 1.1502-33$ A (1955). The old regulations will be designated by the use of (A) after the section number. This is their current designation following adoption of the new regulations.

9 E.g., Treas. Reg. $\$ \S 1.1502-31 \mathrm{~A}$ (b) (1) (i), $-37 \mathrm{~A},-40 \mathrm{~A},-41 \mathrm{~A}$ (1955).

10 INT. REv. CoDE of 1954, § 1012. 
sale of the assets for $\$ 100$, could deduct a $\$ 100$ loss from its income, although the economic unit had never paid the $\$ 100 .^{11}$ To remedy this problem, the regulations provided that any losses on sales by the subsidiary attributable to pre-affiliation events could be offset only against the subsidiary's income. ${ }^{12}$ However, they left open the possibility of depreciating the assets at the higher basis and offsetting the income of the parent, or of transferring the asset at its fair market value to the parent, which in turn would sell it outside the group for its fair market value. As will be seen, ${ }^{13}$ the regulations provided for elimination of the loss and a carryover basis for the asset after the intercompany sale. ${ }^{14}$ Thus, the parent had the high basis asset to determine loss on the ultimate sale and was able to offset the preaffiliation loss against its own income. ${ }^{15}$ In addition, the regulations did not apply to inventory.

\section{Intercompany Sales and Purchases}

The old regulations, as noted, called for elimination of all profit and loss on intercompany transactions. ${ }^{16}$ Thus, if a parent sold an asset with a basis of $\$ 15$ to a subsidiary for $\$ 20$ in cash, the $\$ 5$ gain would be eliminated. In turn, the transferee took the asset at the transferor's basis. Therefore, if the subsidiary sold the asset outside

11 It could be argued that the loss was incurred by the parent through a discount of the tax advantage in the market. However, even if such a discount did occur, there would be a windfall to the seller, since there would be no correlation between the lost opportunity to use the loss and the parent's opportunity to offset it against the income of the parent and the subsidiary. Since such a discounting would occur only if the deduction were allowed, and since there is no reason to foster such discounting, the argument that the loss was incurred in this manner is weak.

One caveat must be acknowledged. If all corporations were viewed as one corporation and if there were a discount of the lost advantage, there would be no need to prohibit an offsetting of the loss. Such a theory would be based on the view that the purpose of the corporate tax is to tax total corporate net income. Under this view, as long as the government received a tax on the total net profits of all corporations, the government would be in its proper position. Every loss would be offset against a profit.

However, such offsetting of one entity's loss against the gain of another, trafficking in losses and a unified corporation theory have clearly been rejected under the present system. See INT. REv. CoDE of 1954, \$\$269, 382, 334(b) (2), 482. See also Libson Shops v. Koehler, 353 U.S. 382 (1957). Therefore, it would seem improper to apply such a theory to the consolidated return area by regulation.

12 Treas. Reg. $\$ 1.1502-31$ A (b) (9) (1955).

${ }_{13}$ See note 16 infra and accompanying text.

14 Treas. Reg. $\$ 1.1502-31 A$ (b) (1) (i) (1955) (elimination provision); Treas. Reg. §1.1502-38A (b) (1955) (carryover provision).

15 This result might be prevented if there were no "business purpose" for acquiring the affiliate other than utilization of this loss. See, e.g., J. D. \& A. B. Spreckels Co., 41 B.T.A. 370 (1940).

16 This applied to any profit or loss on obligations of the members of the group and to transactions within the group involving the stock of a member of the group, in addition to sales of other property. E.g., Treas. Reg. $\$ \S 1.1502-40 \mathrm{~A}$ (bad debts), -41A (bonds) (1955). See also Charles Ilfeld Co. v. Hernandez, 292 U.S. 62 (1934). 
the group for $\$ 20$ in the following year, the group would recognize the $\$ 5$ gain in that period, since the group as a whole had realized the gain for the first time. Problems arose, however, when the parent sold the subsidiary's stock before the asset involved in the intercompany transaction was sold outside the group. For example, suppose a parent purchased, for $\$ 100$, a subsidiary which had no earnings and profits. Subsequently, the parent constructed a building for the subsidiary at a cost of $\$ 50$ and sold it to the subsidiary for $\$ 100$, its fair market value. The subsidiary, in turn, obtained a government loan for $\$ 100$, secured by the building, and used the loan to satisfy the sale price. After three years, ${ }^{17}$ the parent sold the subsidiary for $\$ 100$, since the value of the building was offset by the loan and there had been no other increase in value. If the parent were permitted to deduct its original basis from the amount realized on the sale, there would be no gain. Yet, the parent received $\$ 50$ in tax free money.

These facts were presented in more complex form in Henry $C$. Beck Builders, Inc. ${ }^{18}$ In that case, the purchaser liquidated the subsidiary under section 332 and received a stepped-up basis for the building under section 334(b) (2), making the problem more acute. The Commissioner attempted to tax the gain at the time the stock was sold. He relied on a theory, enunciated in Revenue Ruling 60-245,19 that intercompany gains and losses should be kept in suspense and recognized upon the sale of the stock of the subsidiary, if the asset has not been sold previously. The Tax Court held in favor of the taxpayer and reprimanded the Commissioner for not having issued authoritative regulations to cover the problem, which he obviously knew existed. In the absence of regulations, the court felt that the usual rules regarding annual accounting and basis should apply. It also rejected the Commissioner's argument that the disaffiliation constituted a change of accounting method, which allowed him to reapportion income under section $481 .{ }^{20}$ The court did not feel that the elimination provisions of the regulations were a method of accounting within the meaning of section 446 .

Using the old regulations, the Beck Builders-type device allows the escape of income which otherwise should and would be taxed

17 The purpose of waiting three years is to avoid ordinary income treatment under the provisions of $\$ 341$ of the 1954 Code, applicable to collapsible corporations, if there is any gain at the time of sale.

1841 T.C. 616 (1964). Accord, United Contractors, Inc., 23 C.C.H. Tax Ct. Mem. 453 (1964), aff'd per curiam, 344 F.2d 124 (4th Cir. 1965); Vernon C. Neal, Inc., 23 C.C.H. Tax Ct. Mem. 873, aff'd on rehearing, 23 C.C.H. Tax Ct. Mem. 1338 (1964). Discussions of the problem in Beck Builders are voluminous. See, e.g., Chappell, Closing Beck Builders "Loophole"-The Dilemma of the Intercompany Transaction, 43 TAXES 715 (1965); Dale, Suspense Accounts for Intercompany Transactions, 14 TAX Executive 76 (1961).

19 1960-2 CUM. BULL. 267.

20 INT. REv. CoDe oF 1954, $\$ 481$ (a), provides that, if there is a change of accounting method, the Commissioner shall make adjustments in order to reflect income properly. 
only when there are no earnings and profits in the subsidiary and, in a limited number of cases, when there are only pre-affiliation earnings and profits. ${ }^{21}$ When there are post-affiliation earnings and profits equal to the amount of intercompany profits, the device avoids no tax. For example, assume that a parent purchases 100 per cent of the stock of a subsidiary for $\$ 100$. The subsidiary subsequently has a profit of $\$ 100$ on which the group pays $\$ 50$ tax. The parent then sells a $\$ 50$ basis asset worth $\$ 100$ to the subsidiary for $\$ 100$. At that point, the subsidiary has assets worth $\$ 150$-the original $\$ 100$, plus $\$ 100$ profit less $\$ 50$ tax less $\$ 100$ payment for the intercompany purchase, plus a $\$ 100$ value asset obtained in the intercompany purchase. If the subsidiary were then sold for $\$ 150$, the parent would have $\$ 50$ taxable income. As a result of these transactions, it would have realized $\$ 100$ income, consisting of $\$ 50$ realization on the asset sold to the subsidiary and $\$ 50$ realization from the sale of the subsidiary's stock. However, it has already paid tax on the $\$ 50$ realization on the sale of the asset to the subsidiary when the subsidiary made its $\$ 100$ profit. It will pay tax on the other $\$ 50$ upon sale of the stock. The parent is in no better position than it would have been in had it transferred the asset to the subsidiary and the subsidiary had made a tax-free distribution, ${ }^{22}$ which would not reduce the basis of the stock of the subsidiary in the parent's hands. ${ }^{23}$ These results are proper because one tax has been paid by the economic unit on all income the parent has received. ${ }^{24}$ This was not true in Beck Builders. Under the simplified facts above, the parent realized a $\$ 50$ increment in the basis and value of its assets on which no tax was paid.

If, in the above example, the subsidiary had no post-affiliation earnings and profits but, instead, $\$ 50$ pre-affiliation earnings and profits, the parent would gain $\$ 50$ on which it or the economic unit had not paid tax. The parent had a $\$ 100$ basis in the stock of the subsidiary. It would be transferring an asset with a $\$ 50$ basis to the subsidiary and be receiving cash having a basis of $\$ 100$. If the stock 1964).

21 See F. Peet, Consolmated Tax Returns $\$ 15.04$ (1959), $\$ 10.03$ (Supp.

22 See INT. Rev. ConE of 1954, $\$ 243$ (a) (3), 301(c) (1), 301 (c) (2).

23 Treas. Reg. \$1.1502-33A (1955). See INT. Rev. Code of 1954, \$\$243(a) (3), 301 (c) (1), 301(c) (2). So long as the basis of the stock is not increased to reflect post-affliation earnings and profits, a reduction in the basis of the stock to reflect a distribution from those profits will cause an unwarranted gain. For example, suppose $P$ purchases $S$ for $\$ 100$ and $S$ subsequently has a $\$ 10$ after-tax profit which it distributes. If the basis of the stock is lowered to $\$ 90$, a later sale of the stock for the value of the assets $(\$ 100)$ will result in a $\$ 10$ gain. The corporate entity will have paid tax on the profit when made. Taxation at the sale of the stock results in the entity being taxed a second time on the same income. Tax free dividend distributions between affiliated corporations are permitted under INT. REv. CODE of 1954, \$243, without a consolidated return. In such a case, the basis of the stock is not reduced. Such a reduction would defeat the purpose of making the intercompany dividend tax free-the elimination of multiple taxes on the same income at the corporate level.

24 See text accompanying notes 103-05 infra. 
were sold for $\$ 100$, the fair market value of the assets, there would be no gain at the time of the sale, since the basis of the stock would be $\$ 100$. It appears, at first glance, that this device has provided the parent with a tax free escape of income. However, the old regulations allowed tax free distributions to be made out of pre-affiliation earnings and profits, with no reduction in basis, although such distributions constituted returns of capital. ${ }^{25}$ Therefore, the parent's position would be no better by reason of the intercompany sale than if it had contributed the asset and caused a distribution from the subsidiary's pre-affiliation earnings and profits. Any problem with the result in the example is caused by the rule for distributions from pre-affiliation earnings and profits, not by a peculiar defect in the intercompany profit rules. Moreover, the pre-affiliation earnings and profits rule governs when no consolidated return is filed-if there is avoidance, it can be accomplished without a consolidated return. ${ }^{26}$

The old regulations, however, did disallow losses on the sale of the subsidiary's stock to the extent of distributions out of preaffiliation earnings and profits. ${ }^{27}$ Thus, the intercompany sale of an appreciated asset by the parent at fair market value did place the parent in a better position than a contribution and distribution, when there were only pre-affiliation earnings and profits and a loss resulted from the sale of the stock. ${ }^{28}$ Consequently, the Beck Builders scheme can also be said to have provided an independent avoidance device in this instance.

When there are no earnings and profits in the subsidiary, a sale of the stock for $\$ 100$, in the example, would result in the parent having no gain at sale, yet having $\$ 50$ more than before it acquired the subsidiary. If there had been a contribution and distribution, under section 301 there would have been a reduction of the basis of the stock of the subsidiary in the parent's hands for the excess of distribution over contribution, and a consequent $\$ 50$ gain on the sale. ${ }^{29}$ Therefore, the sale would result in tax avoidance if there were no reduction in basis.

It is important to note that the loan in Beck Builders was not the crux of the problem. If there had been earnings and profits, there would have been no avoidance. For example, assume that the subsidiary is purchased for $\$ 100$ and then earns $\$ 100$ of income on which $\$ 50$ tax is paid. The parent then sells the $\$ 50$ basis building to the subsidiary for $\$ 100$ and the subsidiary borrows $\$ 100$ secured by the building to pay the parent. The parent has $\$ 50$ more basis in its

25 Treas. Reg. $\$ 1.1502-33 A$ (1955). See Int. Rev. CoDE of 1954, §§301, 316.

26 See INT. Rev. Code of 1954, $\$ \$ 243,301,316$.

27 Treas. Reg. $\$ 1.1502-36$ A (1955).

28 There were special rules to prevent avoidance by use of transfers for fictitious consideration. Treas. Reg. $\$ \S 1.1502-36 \mathrm{~A}(\mathrm{a})(1)$, (2) (1955).

29 See PEEI, supra note 21, at $\$ 10.03$ (Supp. 1964). 
assets than before, but the economic unit has paid a tax on this $\$ 50$. The result is the same as it would be had there been a contribution of the building and a distribution of $\$ 100$. If the subsidiary is then sold for $\$ 100$, the fair market value of the assets, there will be no gain on the sale. However, the parent will be only $\$ 50$ better off for having owned the subsidiary and a tax, as illustrated, will be paid on that income.

Because the Beck Builders-type device accomplishes its objectives only in the situations outlined above, one system suggested for handling intercompany sales under the old regulations would have prevented the major portion of the attempted avoidance with no amendment to the regulations. ${ }^{30}$ This system, dubbed the "dividend" method, ${ }^{31}$ provided that all intercompany sales be treated as a transfer of the asset at basis and a net contribution or distribution of the difference, as the case might be. In the case outlined, where there was a sale and the subsidiary had no earnings and profits, the parent's basis in the subsidiary's stock would be reduced because there would be a net distribution from capital if the transaction were viewed as a transfer at cost and a distribution of the excess by the subsidiary to the parent. The same result would be reached if there were a sale at a profit and a loan in excess of basis by a subsidiary without earnings and profits to pay for the purchase. If a parent pays $\$ 100$ for a subsidiary without earnings and profits, builds a building for $\$ 50$, sells it to the subsidiary for $\$ 100$, and the subsidiary borrows $\$ 100$ on the building and pays the parent, the parent's basis in the subsidiary's stock will be reduced to $\$ 50$. This is what would occur if there were a transfer of a $\$ 50$ basis asset for $\$ 50$, followed by a distribution of $\$ 50$. If the parent then sells the subsidiary for $\$ 100$, its fair market value, there would be a $\$ 50$ gain and no escape from tax. ${ }^{32}$

There is one significant problem with this solution. It is caused by an aberration from outside the consolidated return area. Section $312(\mathrm{j})$ provides that, where there is a government-insured loan in excess of the basis of an asset securing the loan, the earnings and profits of the borrower shall be increased by the amount of the excess at the time of any distribution to the shareholders. The purpose of this section is to provide for taxable dividend treatment when a distribution is made from such a de facto realization, even if no tax has yet been paid at the corporate level. ${ }^{33}$ If applied in the consolidated return area, section $312(\mathrm{j})$ would defeat the "dividend" method as a

30 See id. § 15.04 (1959), § 10.03 (Supp. 1964).

31 Note, 78 HaRv. L. Rev. 1415, 1432 (1965).

32 The court in Beck Builders rejected this solution to the problem. 41 T.C. at 616 n.17.

33 Section 312(j) was not applicable to the years involved in Beck Builders. It was applicable to the years in Vernon C. Neal, 23 C.C.H. Tax Ct. Mem. 873, aff'd on rehearing, 23 C.C.H. Tax Ct. Mem. 1338 (1964). However, the Neal court made no mention of the section. 
solution to the Beck Builders-type case, as its proponent recognized. For example, assume that a parent purchases a subsidiary with no earnings and profits for $\$ 100$, followed by a sale of a $\$ 50$ basis building to the subsidiary for its value of $\$ 100$ with a government-insured loan obtained by the subsidiary for $\$ 100$, secured by the building, to pay for the purchase. Applying the solution outlined, the $\$ 50$ net distribution to the parent would be a dividend, not a return of capital, because the earnings and profits of the subsidiary would be raised under section $312(\mathrm{j})$ for the excess of the loan over the basis. Moreover, if section $312(j)$ were not applied, its purpose would be defeated, since later distributions to the shareholders of the parent, although ultimately derived from the loan in excess of basis, would not constitute a dividend. ${ }^{34}$

\section{Distributions}

As has been noted, the elimination and carryover basis rules of the old regulations applied to distributions as well as sales. ${ }^{35}$ However, the normal rules applied with regard to crediting the parent's earnings and profits for dividends and to lowering the basis of the stock if there were a return of capital. ${ }^{36}$ This meant that distributions to the parent's shareholders, if out of a dividend from the subsidiary to the parent, were taxed as a dividend. One exception to these rules was that, if a return of capital resulted from a distribution of property in an amount in excess of the basis of the subsidiary's stock, the gain was not recognized. ${ }^{37}$ This was in accord with the theory that the

34 Professor Dale has argued that if a carryover basis is given to the asset in the intercompany sale, there is no problem in Beck Builders, even without a reduction in the basis of the stock. Since the asset has such a basis, a purchaser of the stock will always pay less for the stock-the price will be reduced by the amount of the future tax on the unrealized appreciation of the asset. The only time, he claims, that this discounting will not occur is if the purchaser obtains a step-up through $\$ 334(\mathrm{~b})(2)$, as in Beck Builders. He argues that this problem is caused by $\$ 334(\mathrm{~b})(2)$, not by the intercompany sale. The $\S 334$ (b) (2) step-up available to the buyer will often be passed on to a seller who does not receive a discounted price for assets with unrealized appreciation because the buyer will obtain a step-up and not have to pay the tax. Dale, supra note 18.

There are a number of problems with this approach: 1) it depends on an unproved and uncertain discounting mechanism to prevent a windfall to a taxpayer; 2) even if the discounting does occur, although the seller "gets away with nothing," the government's tax may be deferred in perpetuity if the buyer does not sell the asset or depreciate it (at any rate there will be a substantial delay in the payment of the $\operatorname{tax}$ ); and 3 ) the tax system has consistently refused to rely on such a market mechanism to regulate the tax system and properly allocate tax burdens. See INT. REv. CoDE of $1954, \S 269$. Following the Dale rationale, every time a taxpayer is found to have present realization, instead of imposing a tax, the taxpayer's assets should be maintained at the pre-tax basis and the tax postponed.

35 Treas. Reg. $\$ \$ 1.1502-31 \mathrm{~A}$ (b) (1) (i), -38A (b) (1955).

36 Treas. Reg. § 1.1502-33A (1955) ; American Water Works Co. v. Commissioner, 243 F.2d 550 (2d Cir. 1957) ; Freedman v. United States, 157 F. Supp. 613 (N.D. Ohio 1958); Taylor-Wharton Iron \& Steel Co., 5 T.C. 768 (1945); I.T. 3758, 1945-1 Cum. BuLL. 159.

37 See Treas. Reg. $\$ 1.1502-31 \mathrm{~A}$ (b) (2) (iii) (1955); INT. REv. CodE of 1954, $\S 301$ (c) (3) (B). 
entity had no profit. However, if the return of capital was in cash or in the form of a cancellation of indebtedness, Revenue Ruling 57-201 ${ }^{38}$ provided that the cash in excess of basis would be taxed under section 302. This was done, despite the inconsistency with the "entity theory," because it was apparently felt that if the gain were not taxed at that time, it would never be taxed. ${ }^{39}$ Unlike property, the basis of cash could not be lowered, postponing the gain until realized outside the group. Giving the stock a negative basis evidently was not considered. This same rule also applied to partial and complete liquidations not falling within section 332 and to section 302 (a) redemptions. ${ }^{40}$ Thus, gain was recognized although the group as a whole had no gain. In addition, the distributor in a section 334(b) (2) liquidation was taxed under section 1245 and section 1250,11 apparently because the statutory scheme demanded a tax in return for a step-up in the basis of assets, even if that step-up took place within a single entity.

\section{Sale of the Stock}

The general theory of the regulations called for the stock of the subsidiary to be treated as it would be if no consolidated return were filed, causing a number of the problems heretofore mentioned. ${ }^{42}$ There were, however, certain exceptions. Most significant was a reduction in the basis of the stock for the subsidiary's losses, availed of by the parent or other affiliates against their income, which the subsidiary could not have offset against its own income. ${ }^{43}$ This provision was designed to prevent double deduction of losses by the parent. $^{44}$

For example, suppose that a parent corporation buys a subsidiary for $\$ 100$ and the subsidiary then has losses of $\$ 50$ which are offset against the parent's income on the consolidated return. If the parent then sells the stock of the subsidiary for $\$ 50$, the fair market value after the loss, it will have another $\$ 50$ loss on that sale. The regulations prevented this result. ${ }^{45}$ If the losses were in excess of the stock's basis, the double deduction was prevented by reducing the

38 1957-1 CuM. BuLz. 295.

39 Id. at 296.

40 Treas. Reg. $\$ \S 1.1502-37 A$ (a) (1) (i), (ii) (1955). In addition, gain was recognized in a complete liquidation not within $\$ 332$ of the 1954 Code if followed by a termination of the business of the subsidiary. Treas. Reg. $\$ 1.1502-37 \mathrm{~A}$ (a) (1) (i) (1955).

41 Treas. Reg. \$1.1502-37A (a) (1) (iii) (1963).

42 See Treas. Reg. \$1.1502-33A (1955).

43 Treas. Reg. $\$ 1.1502-34 A$ (1955).

44 See PEEL, supra note 21, \$14.02, at 206.

45 Authority for adjusting the basis in this way can be found in $\$ 1051$ of the 1954 Code, which authorizes regulations adjusting the basis of property held by affiliates during years a consolidated return was filed for items relating to such con- 
basis of obligations in the hands of the affiliates. ${ }^{46}$ However, if the losses exceeded all bases, a double deduction for the losses would result since there was no provision for a negative basis. ${ }^{47}$ For example, suppose that a subsidiary with a basis to its parent of $\$ 100$ has a loss of $\$ 400$ which the parent offsets against its own income. In addition, the subsidiary remains solvent because of appreciation in assets and has supported its losses by loans to enable it to have a $\$ 400$ loss with only $\$ 100$ initial net basis in its assets. Suppose further that the subsidiary is then sold for $\$ 100$. There would be no tax at sale despite an actual $\$ 400$ gain.

In addition to this provision, two other exceptions to the general rule were felt necessary. The first, already mentioned, ${ }^{48}$ was that losses on the sale of the stock were disallowed to the extent of distributions out of pre-affiliation earnings and profits. The second, in part a corollary to the first, provided that if a transfer were made within a group for fictitious consideration, any loss on the sale of the subsidiary's stock would be disallowed to the extent that the subsidiary suffered the adverse effect of the transfer. ${ }^{49}$

The first exception was calculated to prevent the following situation. A parent buys, for $\$ 400$, a subsidiary which has $\$ 300$ of earnings and profits at the time. The parent then distributes all of the earnings and profits to itself, tax free, followed by a sale of the subsidiary for $\$ 100$. Without this provision, the parent would be allowed a fictitious loss on the sale of the stock. If the policy behind disallowing the loss is sound, it also should be applied to decrease gains, thus treating distributions from pre-affiliation earnings and profits as returns of capital which reduce the basis of the subsidiary's stock in the parent's hands. However, one problem with the regulation is that distributions of pre-acquisition earnings and profits are a return of capital, ${ }^{50}$ but are not treated as such outside the consolidated return area. ${ }^{51}$

The second exception was to serve much the same purpose as the provision just discussed. If a parent has an asset with a fair market value and basis of $\$ 10$ and transfers it to the subsidiary for $\$ 20$, the subsidiary has, in effect, made a distribution. Since the distribution

solidated return periods. See PEer, supra note $21, \S 14.02$, at 206 . In addition, the legislative history of the consolidated return provisions calls for regulations to determine the extent of gain or loss to be recognized on the sale of an affiliate's stock for transactions occurring during affiliation. S. REP. No. 960, 70th Cong., 1st Sess. 15 (1928). This provides ample authority for general departure from the basis rules applied outside the consolidated return area.

46 Treas. Reg. $\S 1.1502-35 A$ (1955).

47 See Cooper, Negative Basis, 75 HaRv. L. Rev. 1352, 1371-72 (1962).

48 See note 27 supra and accompanying text.

40 Treas. Reg. $\$ \$ 1.1502-36 A(a)(1),(2)$ (1955).

50 See note 25 supra and accompanying text.

51 InT. REv. CODE of 1954, $\$ \$ 301$ (c), 316(a) (1). Since 85 per cent of all intercorporate dividends are excluded from income, INT. REv. CoDE of 1954, 243 (a) (1), and since a 100 per cent exclusion is available under $\$ 243$ (a) (3), fictitious losses could be obtained without a consolidated return. 
would be a return of capital if made directly, the provision is justified, but it also should have been applied to reduce the basis so that gains are lowered and losses disallowed. If there are pre-acquisition earnings and profits only, the merits of the provision are subject to the merits of the pre-acquisition earnings and profits provision. If the corporation has post-acquisition earnings and profits, application of the provision is unreasonable since the distribution could have been made by a direct distribution, with no disallowance of loss at sale. ${ }^{\mathbf{2}}$ This very fact makes it unlikely that such a transfer would occur.

One final problem with the rule providing that intercompany stockholdings be treated as they are when no consolidated return is filed was raised in Remington Rand, Inc. v. Commissioner. ${ }^{53}$ The taxpayer argued, to no avail, that the basis of the stock of the subsidiary should be increased to reflect the post-acquisition earnings and profits of the subsidiary when consolidated returns were filed. It pointed out that the parent could have caused the subsidiary to declare a dividend of the earnings and profits tax free and then contributed them back to the subsidiary, thereby receiving a stepped-up basis, and that the same result should obtain where these formal steps were not taken. The court literally relied on form over substance to reject this argument. Thus, the profits of affiliates were taxed twice at the corporate level if no distributions were made of the post-acquisition earnings and profits, even when the corporations were filing a consolidated return and were theoretically one corporation for tax purposes.

\section{The Solution of the New Regulations}

\section{Acquisition of Stock}

It will be recalled that the old regulations allowed certain built-in losses to offset the income of the parent and other affiliates. ${ }^{54}$ The new regulations attempt to resolve this problem by treating all built-in losses, when they are realized, as if they had been realized in a year in which the subsidiary was not a member of the group. ${ }^{55}$ As a result, the subsidiary is generally able to deduct the loss in the year it is realized from its income only and to carry it up and back only to the separate income of the subsidiary. ${ }^{56}$ This applies to all assets and depreciation. Thus, if a parent purchases a subsidiary for $\$ 100$ with a sole depreciable asset having a basis of $\$ 500,80$ per cent of

62 INT. REv. CODE of 1954, $\$ 243$ (a) (3), 301 (c) (1), 301(c) (2).

5333 F.2d 77 (2d Cir.), cert. denied, 280 U.S. 591 (1929).

54 See notes 13-15 supra and accompanying text.

55 Treas. Reg. $\$ \$ 1.1502-15$ (a) (1), (2) (1966).

56 Treas. Reg. $\$ \$ 1.1502-21$ (c), -22 (c), -79 (1966). For an extensive discussion of these limitations and the changes made in the rules for carryovers from a separate return year by the new regulations, see Salem, supra note 7. The rules concern the same types of situations covered by $\$ 382$ of the 1954 Code. 
the depreciation on that asset will be offset each year against the income of the subsidiary only. The same rule applies to all other losses which were accrued before the subsidiary became a member of the group. A transfer of the asset to the parent at fair market value no longer utilizes the loss for the parent, because a carryover basis on intercompany sales is no longer used..$^{57}$

Three exceptions are made to this general rule. It does not apply retroactively to subsidiaries which became members of the group before October $1,1965 .^{58}$ It also does not apply to subsidiaries which have become members of the group at least ten years before the loss is realized. $^{59}$ Finally, it does not apply if the amount by which the basis of the assets at the time of affiliation exceeds the fair market value of these assets at that time is 15 per cent or less. ${ }^{60}$

\section{Intercompany Profit and Loss on Sales}

In response to the problems illustrated by Beck Builders, the regulations established a deferred accounting system. ${ }^{61}$ Under this system, profit or loss of the selling member of the affiliated group is placed in a deferred profit and loss account. ${ }^{62}$ The purchaser obtains a cost basis rather than a carryover basis for the asset. ${ }^{63}$ The profit or loss is taken into account by the selling member when the asset is sold outside the group or when the selling or buying member leaves the group. ${ }^{64}$ If the asset is depreciated, the seller recognizes profit at the same rate as the buyer depreciates. ${ }^{65}$ These amounts cancel out, leaving the group paying tax as if there were a carryover basis for the asset on a consolidated return. The remaining profit, above depreciation, is recognized under the circumstances outlined above. To il-

57 Treas. Reg. $\$ 1.1502-31$ (a) (1966).

58 Treas. Reg. $\$ 1.1502-15$ (a) (3) (ii) (1966).

59 Treas. Reg. $\$ 1.1502-15$ (a) (4) (i) (1966).

60 Treas. Reg. $\$ 1.1502-15$ (a) (4) (ii) (1966). Cash, good will or marketable securities are excluded from assets for purposes of this computation.

61 Treas. Reg. $\$ 1.1502-13$ (1966). The deferred accounting system does not apply to non-capital expenditures because the income and expense will balance each other out on the consolidated return every year. The system follows the principles in Rev. Rul. 245, 1960-2 CuM. Bull. 267, which was rejected in Beck Builders. See text accompanying note 18 supra.

62 Treas. Reg. $\$ 1.1502-13$ (c) (1966). Gains and losses on obligations of members realized within the group are also adapted to the deferred accounting system. Treas. Reg. $\$ 1.1502-14$ (d) (1966).

63 Treas. Reg. \$1.1502-31 (1966).

64 Treas. Reg. $\$ 1.1502-13(f)$ (1966). The new regulations use "recognized" in a new way. Income and loss is "recognized" when it would be if no consolidated return were filed, but taxation is deferred until the income or loss is "taken into account." See Treas. Reg. $\$ \$ 1.1502-13$ (c), (f) (1966). This dichotomy did not appear in the original proposals. See Proposed Treas. Reg. (I) $\$ \$ 1.1502-13$ (c), (f), 30 Fed. Reg. 12571, 12572 (1965). Normally, if deferral is appropriate, "recognition" is deferred. See INT. REv. CoDE of 1954, \$351. For a possible problem caused by this new language, see Cohen, Final consolidated return regs benefit some groups but increase tax for others, $26 \mathrm{~J}$. TAxation 2, 4 (1967).

65 Treas. Reg. \$1.1502-13(d) (1966). 
lustrate, suppose a parent sells an asset with a basis of $\$ 10$ to its subsidiary for $\$ 20$. The subsidiary takes a $\$ 20$ basis in the asset and $\$ 10$ goes into the parent's deferred profit account. If the asset is sold for $\$ 20$, the parent recognizes the $\$ 10$ profit on the consolidated return. If, on the other hand, the subsidiary is sold, the profit is recognized at that time. If the subsidiary is purchased for $\$ 100$, the parent sells it the asset described above and nothing else changes, the subsidiary's stock would sell for $\$ 100$, assuming that the asset transferred in the intercompany sale had a fair market value of $\$ 20$. Under the deferred accounting system, this $\$ 10$ is taxed to the parent when the subsidiary leaves the group. The subsidiary receives a $\$ 20$ basis for the asset. If the asset has been depreciated by 10 per cent or $\$ 2,10$ per cent deferred profit or $\$ 1$ will be recognized at that time. If the asset or the stock is later sold, the remaining $\$ 9$ of profit then will be recognized. If the subsidiary had sold to the parent for $\$ 20$ an asset with a $\$ 10$ basis, the same mechanism would operate. The parent would obtain a $\$ 20$ basis in the asset. If it sold the asset for $\$ 20$, the profit would then be recognized. If it sold the subsidiary, the subsidiary would recognize the profit at that time. ${ }^{66}$

\section{Distributions and Sale of the Stock}

The new regulations make a major change in the treatment of the basis of the stock of the subsidiary. The cost approach is abandoned. In its place, the regulations provide that the basis of the stock of a subsidiary in its parent's hands reflect changes in the basis of the net assets of the subsidiary. ${ }^{67}$ This approach adopts what accountants call the "book value" or "equity" method, ${ }^{68}$ which has been advocated by legal commentators. ${ }^{69}$ Under this approach, which overrules Remington Rand, the basis of the stock is increased to reflect the parent's share of post-acquisition earnings and profits as well as any post-acquisition decline in earnings and profits of the subsidiary, preventing these earnings and profits from being taxed twice at the corporate level. As a corollary, all distributions (including dividends) now reduce the basis of the stock by the amount of the distribution under section $301 .^{70}$ If this were not done, the parent would show a fictitious loss at sale. At any rate, if the earnings are an increase in capital, it is clear that a distribution of them is a return of capital. Dividend income on these distributions continues to be eliminated, as before. The inclusion of these new rules led to the elimination of the "losses availed of" provision and deletion of the provision disallowing

68 See examples given in Treas. Reg. $\$ 1.1502-13(\mathrm{~h})$ (1966).

67 Treas. Reg. \$1.1502-32 (1966).

68 See, e.g., W. Karrenbrock \& H. Simons, Advanced Accounting 301-578 (3d ed. 1961).

60 See Note, 78 Harv. L. Rev. 1415 (1965).

70 Treas. Reg. $\S \S 1.1502-32$ (b) (2) (iii), -14(a) (2) (1966). 
losses to the extent of distributions from pre-affiliation earnings and profits. The provision for disallowing losses to the extent of fictitious consideration in intercompany transfers was also eliminated. It is no longer necessary, since the deferred profit account arising from the transfer will be recognized as gain at the time of the later sale of the asset or disaffiliation. ${ }^{71}$

In another major innovation, an excess loss account is used if either the losses or distributions exceed the basis of the stock. ${ }^{\mathbf{7 2}}$ The excess loss account is treated as a capital asset and is recognized as each share of stock is sold, the entire account being recognized when affiliation ceases. It is treated, at least in part, much as a negative basis for stock would be treated.

With regard to losses, the new approach solves the problem of double deduction mentioned earlier. If a parent purchases a subsidiary for $\$ 100$, the subsidiary incurs $\$ 400$ of losses and this is followed by a sale of the stock for $\$ 100$, there will be a $\$ 100$ gain on the sale of the stock and a $\$ 300$ gain from the excess loss account. To the extent that the excess loss account is used, this overrules Revenue Ruling 57-201 so far as distributions are concerned. If there is a redemption or partial liquidation instead of a section 301 (c) distribution, gain is recognized if the amount of cash received exceeds the basis of the stock redeemed. However, the gain is deferred and is not taken into account until either the subsidiary or the parent leaves the group. ${ }^{73}$ The effect is much the same as it would be if the basis of the remaining stock were lowered, as in a section 301 distribution. However, Revenue Ruling 57-201 still governs the complete liquidation not covered by section 332, where gain continues to be recognized and taken into account. ${ }^{74}$ In the redemption and partial liquidation situations, loss will be recognized, although deferred, if only cash is distributed. ${ }^{75}$

The rules governing basis of assets in section 301 distributions were also changed. Instead of taking a carryover basis, ${ }^{76}$ the asset

71 For example, if an asset with a basis and a fair market value of $\$ 100$ were sold by $P$ to $S$ for $\$ 200$, a $\$ 100$ deferred profit would be taken into account by the parent upon sale of the subsidiary. Thus, no avoidance of gain or reduction of loss that would occur through distribution of pre-affiliation earnings and profits can be obtained.

72 Treas. Reg. $\$ \S 1.1502-19$ (a), (b) (1966). This is not true if the subsidiary has a net worth of zero. In such a case the loss is ordinary income, unless the taxpayer can show that it arose from a capital loss. Id.

73 The member is treated as if it disposed of all its stock when the member or the subsidiary ceases to be a member, or when the stock of the subsidiary becomes worthless. Id.

74 Treas. Reg. \$1.1502-14(b) (1966).

75 Treas. Reg. $\$ 1.1502-14$ (b) (1966). This type of deferral means that a gain will be recognized to the parent and taken into account at disaffiliation. This is the identical result obtained by use of the excess loss account. Since the redemption is an exchange under $\S 302(\mathrm{a})$, it will be a capital gain, as is the gain from the excess loss account.

${ }^{76}$ Treas. Reg. $\$ 1.1502-14$ (b) (2) (ii) (1966). 
now takes the same basis as it would under section 301 without a consolidated return. ${ }^{77}$ As for redemptions and liquidations, the assets distributed take the basis of the stock given up, plus liabilities, less cash received. ${ }^{78}$ This use of a substituted basis is a method of deferring the gain on the redemption or liquidation which was not recognized and deferred as described previously. ${ }^{79}$

The deferred accounting system, rather than elimination, is used in the distribution area, if there would normally be a gain recognized to the distributor. In such a case, the gain is subject to the rules for deferred gain on sales. However, here again, if there is a complete liquidation, gain is recognized and taken into account immediately. ${ }^{80}$

It should be noted that, under this new system, distributions from pre-affiliation earnings and profits reduce the basis of the stock of the subsidiary in the parent's hands; this would not be the case if a consolidated return were not filed.

\section{Earnings and Profits}

In keeping with the deferred accounting system, the earnings and profits of the member first selling the asset within the group are to increase or decrease when a deferred gain or loss is taken into account. ${ }^{81}$ Thus, if $P$ sells an asset with a basis of $\$ 15$ to $S$ for $\$ 20$ and the asset is then resold for $\$ 20$ outside the group, the $\$ 5$ deferred gain to $P$ is taken into account upon sale outside the group and the parent's earnings and profits are increased by $\$ 5$. A distribution then made to $P$ 's shareholders would be a dividend. This apportionment took place under the old regulations only when the sale was made outside the group in the same year as it was made to the affiliate. ${ }^{82}$ Also, under the new system, if the parent sells its subsidiary and the subsidiary has deferred profit or, if the parent sells the asset outside the group, the subsidiary's earnings and profits are increased. Thus, any distribution to the minority interest of the subsidiary will be a dividend.

In addition, in the original version of the final regulations, the earnings and profits of the parent were to increase and decrease to reflect the increases and decreases in the earnings and profits of the subsidiary. ${ }^{83}$ This was a corollary to the provision calling for the

77 Treas. Reg. $\$ 1.1502-31$ (b) (1) (1966).

78 Treas. Reg. $\$ 1.1502-31$ (b) (2) (1966).

79 If a $\$ 100$ share of stock is redeemed with an asset worth $\$ 200$, the asset is given a $\$ 100$ basis and no gain is taken into account. If the asset is then sold for $\$ 200$, the gain will be taken into account at that point, since it is realized outside the group.

80 Treas. Reg. $\$ 1.1502-14$ (c) (1966).

81 Treas. Reg. $\$ 1.1502-33$ (a) (1966).

82 See Corco Oil Refining Corp. v. Helvering, 72 F.2d 177 (D.C. Cir. 1934) (allocation when sale is in the same year); Rev. Rul. 186, 1956-1 CuM. BurL. 441 (no allocation if in a separate year).

83 Proposed Treas. Reg. (II) §1.1502-33(c) (4), 31 Fed. Reg. 16700 (1966). 
basis of the parent's holdings in the subsidiary's stock to reflect such changes. This meant that if the parent made a distribution to its shareholders when it had no earnings and profits of its own, but its subsidiary had undistributed earnings and profits acquired since affiliation, the distribution would be a dividend and the parent's shareholders would be taxed accordingly.

However, in the finally adopted regulations, a one-year period has been provided in which this treatment is elective. ${ }^{84}$ If the election is not made, the earnings and profits of the subsidiary are not reflected in the earnings and profits of the parent. ${ }^{85}$ Instead, at the time of the sale of the stock, the earnings and profits will be increased or decreased in an amount equal to the gain or loss which would have been reflected in earnings and profits if no adjustments to the basis of the stock had been made to reflect post-affiliation increments and deficits in the subsidiary's earnings and profits. This results in earnings and profits being treated just as they were under the old regulations, or as if separate returns were filed. The Treasury reserved its decision on the solution to be employed after December 31, $1967 .{ }^{86}$

\section{Evaluation of the Regulatrons}

In considering the issues raised by the regulations, it is important to note, at the outset, the similarity between the consolidated return and a stock purchase by the parent of the affiliate's stock, followed by liquidation of the subsidiary and operation as one corporation, with eventual sale of the subsidiary's assets or reincorporation and sale of the subsidiary's stock. The stated purpose of the consolidated return provision is to treat the affiliate as one corporation with branches. Given this purpose, the analogy to the liquidation is important for two reasons. First, statutory choices as to treatment in the liquidation area might impose some responsibility on the Commissioner to follow these results in the consolidated return area. Second, and more important, what happens in the liquidation area may help to conceptualize what is being attempted in the consolidated return area.

\section{Acquisition of an Affiliate}

Both the old and the new regulations have chosen not to allow built-in losses on high basis assets to offset income of the other affiliates. Thus, if $P$ buys $S$ stock for $\$ 100, S$ has a single asset with a basis of $\$ 200$ and $S$ sells the asset after affiliation for $\$ 100$, the loss may be used only against the income of $S$. Carryovers of the loss are also

84 Treas. Reg. $\$ 1.1502-33$ (c) (4) (iii) (1966).

85 Treas. Reg. $\$ 1.1502-33$ (c) (4) (i) (1966).

86 Treas. Reg. $\$ 1.1502-33$ (c) (4) (ii) (1966). 
limited to the subsidiary's separate income. ${ }^{87}$ Three issues are raised by this regulation: (1) is the choice not to allow the built-in loss to offset the parent's profits sound? (2) should any such loss be allowed to offset the subsidiary's income and, if so, to what extent? (3) should a corollary be provided for built-in gains, by allowing the basis of the subsidiary's assets to be raised when the parent purchases the stock for more than the basis of the assets?

Not allowing the high basis assets to offset income of the parent is consistent with the provisions of the Code which prohibit the income of one economic entity from offsetting that of another. ${ }^{88}$ This principle is illustrated in the analogous liquidation area by Kimbell-Diamond Milling Company. ${ }^{89}$ The simplified facts of that case were that the parent purchased for $\$ 100$ the stock of a subsidiary having assets with a $\$ 500$ basis. After a section 332 liquidation, it depreciated the assets using a carryover basis under section $334(\mathrm{~b})(1)$ (since the case pre-dated section 334(b) (2)). The court likened the liquidation to a direct asset purchase and required that the basis be stepped-down to the basis of the stock. Section 334(b) (2) codified this decision ${ }^{90}$ for liquidations occurring within two years of purchase. It applies only to purchases, since the problem arises only in such situations. Allowing the loss would give the parent the advantage of reducing its profits by a loss which it never incurred. ${ }^{91}$

87 Treas. Reg. \$1.1502-15 (1966).

88 See INT. REv. CODE of 1954, $\$ 382$ (a) (disallowing the use of a loss carryover to a corporation if there is a change of ownership of over 50 per cent and the corporation does not continue to carry on substantially the same trade or business); INT. REV. CODE of $1954, \S 269$ (denying use of a deduction to a corporation, if control of the corporation was obtained by a person for the principal purpose of utilizing losses and deductions not otherwise available to the acquirer); INT. REv. CoDE of $1954, \S 382$ (b) (after a $\$ 381$ (a) (2) reorganization, any pre-acquisition loss carryover shall be drastically reduced if the shareholders of the transferor corporation own less than 20 per cent of the stock of the reorganized corporation).

8014 T.C. 74 (1950), aff'd per curiam, 187 F.2d 718 (5th Cir.), cert. denied, 342 U.S. 827 (1951).

90 The court in Kimbell-Diamond seemed to require an intent to liquidate not required by section 334 (b) (2). 14 T.C. at 80 .

$81 \mathrm{See}$ note 11 supra. It was stated earlier that three exceptions to the rule of Treas. Reg. \$1.1502-15 (1966) were made. See notes 58-60 supra and accompanying text. The exception for a loss built-in over 10 years before realization would appear to be based on a policy that it is too difficult to determine value at that point. This is a valid policy, better served, however, by providing that all built-in losses be determined at the time of affiliation, but that in no case would the new regulation apply to affiliates joining the group over 10 years before the effective date of the new regulation. This was the provision in the original proposals. Proposed Treas. Reg. (I) $\S 1.1502-15$ (1), 30 Fed. Reg. 12575 (1965). The regulation also does not apply retroactively to subsidiaries which became members of the group before January 1, 1966. Since Treas. Reg. $\$ 1.1502-31 \mathrm{~A}(\mathrm{~b})(9)$ (1955) was always applicable in principle to prevent built-in losses, there seems to be no need to make the new regulation prospective only. The principal beneficiaries of prospective application are those using stratagems to avoid the old rule. See text accompanying notes 13-15 supra. Any reliance on the right to use the loss is not likely to be financial, since it is unlikely that the use of the loss was discounted. Seb note 11 supra. However, this prospective application is arguably justified to protect those who might have relied financially. 
The regulations do allow this loss to offset income of the subsidiary, subject to limitations provided for losses incurred in a separate return limitation year. ${ }^{92}$ This raises the question of whether any offset of this loss should be allowed. If this were a section 332 liquidation, under section 334(b) (2), the loss would be completely lost in the step-down. In addition, it has been argued that to allow the loss to be carried to the separate income of the subsidiary allows the parent to inflate that income artifically and thus obtain the benefit of the loss. ${ }^{93}$

Three arguments, however, can be made in favor of allowing the loss. First, if no consolidated return were filed, the loss could be taken, yet there would be an equal potential for artificial inflation of the income. ${ }^{94}$ Second, the loss this entity incurred with dollars on which tax was paid could never be taken at the corporate level, if the loss were disallowed at this point; yet the parent can be said to have borne the loss in the sense that the tax advantage of offsetting it against the income of the subsidiary may have been discounted in the market. The recipients of this premium arguably are receiving not a windfall but rather their just tax rewards, since they are the holders who bore the loss. Third, any minority interest of the subsidiary did bear the loss through depreciation in its stock, yet is not being afforded the opportunity to have its corporation recoup at the corporate level.

The separate return argument merely indicates that it might be a good idea to have mandatory consolidated returns for affiliated groups. In addition, where the affiliates wish to be treated as one corporation, there is no reason why they should be allowed to retain all the benefits of separate entities. The discounting of the loss argument is just as applicable to the liquidation analogy, yet is ignored in that area. ${ }^{95}$ Even if there were a direct sale of assets to the parent instead of a sale of the stock, the loss might be disallowed under section

The third exception provides that no built-in losses are to be disallowed unless the basis of the assets (exclusive of cash, marketable securities and good will) exceeds the fair market value of those assets by over 15 per cent. This exception may be based on a desire to prevent the worst abuse, or the difficulty of evaluation and allocation between assets. See Salem, How to use net operating losses effectively and the new consolidated return regulations, $26 \mathrm{~J}$. TAXATION 270 (1967). However, $\S 334(\mathrm{~b})(2)$ of the 1954 Code requires such valuation and difficulties therein do not seem to warrant the windfall to the parent.

92 See note 56 supra.

93 See Note, 78 HARV. L. REv. 1415, 1422 (1965).

94 See Commissioner v. British Motor Car Distribs., Ltd., 278 F.2d 392 (9th Cir. 1960) ; INT. REv. CoDE of 1954, $\$ 482$. It also seems that this same possibility exists when losses are disallowed under $\$ 269$ and $\$ 382$ of the 1954 Code.

95 The question of whether the loss is really discounted may turn on the certainty of the rule. Therefore, it may be circular to argue that the reason not to allow the loss is that it is not discounted. The discounting here is distinguishable from any discounting of the advantage of using the loss to offset the parent's income because, unlike that situation, the opportunity for the seller to avail itself of the loss if it had kept the subsidiary is much the same as the opportunity of the parent to use the loss against the subsidiary's income. 
337. The minority interest argument is more persuasive. There would be no continuing minority interest in the liquidation analogy. At liquidation, its lost tax advantage might theoretically be accommodated in the amount of stock or property given it by the parent. ${ }^{96}$ However, any attempt to protect such an interest would run the risk of the parent transferring income to the subsidiary and the section 482 weapon presents difficult administrative problems. ${ }^{97}$ These disadvantages seem to outweigh the interest of the minority. This is especially true in the liquidation situation since it is questionable whether the minority would be compensated for the lost advantage, because the parent would not have obtained it.

The final question in this area is whether the basis of the assets should be stepped-up to the basis of the stock when the parent pays more for the stock than the basis of the assets. ${ }^{98}$ Since the parent paid dollars with a tax basis for the subsidiary, it seems inequitable, at first glance, to force it to take a lower basis than it paid for the assets. This is especially true when one is treating the purchase as if the assets were being brought into the parent, ${ }^{99}$ rather than treating the parent as if it were an individual investing in a separate corporate entity, as one would outside the consolidated return area. Moreover, a step-up given under section 334(b) (2) in the liquidation area had been allowed under the Kimbell-Diamond doctrine prior to the enactment of that section. ${ }^{100}$ It could be argued that this mechanism allows a corporate tax on the appreciation in the assets to be lost. While this is true, it also happens in the liquidation area; yet the statutory scheme has chosen to exempt the asset appreciation from tax both in the section 334 (b) (2) situation and, under section 337, when there is a direct asset sale to the parent pursuant to a plan of complete liquidation, rather than a sale of the subsidiary's stock to the parent. This decision was made by Congress in an analogous situation-it appears inconsistent to depart from it in the consolidated return area. However, one distinction which can be made between the consolidated return and the liquidation is that the basis of the stock would not be lost to the parent in the former situation, as it would be in a liquidation if no step-up were given. In other words, if a parent purchases, for $\$ 100$, the stock of a subsidiary which has a basis in its assets of $\$ 50$ and liquidates it with the assets receiving a basis of $\$ 50$, the parent

96 Even if this discounting does not take place, the minority is a deserving group, since its corporation will have a loss followed by income, yet will not be able to average because of what has happened to the rest of the stock.

97 Section 482 of the 1954 Code gives the Commissioner power to apportion income between affiliates in order to reflect accurately the separate income of each affiliate.

98 See Note, 78 Harv. L. Rev. 1415, 1420-23 (1965).

99 This makes it seem closer to a direct asset purchase.

100 Montana-Dakota Utilities Co., 25 T.C. 408 (1955), acquiesced in, 1956-2 CuMr. Bull. 7. 
loses $\$ 50$ of its basis forever. In the consolidated return situation, if the bases of assets are not stepped-up, the parent will continue to have a $\$ 100$ basis in the stock. If the stock is later sold for $\$ 50$, the parent will have a loss. If the assets are sold or there is a section 351 reincorporation and sale of the stock for $\$ 50$ in the liquidation situation, there will be no loss. Nevertheless, the possible use of the basis in the future does not seem to justify loss of the basis while the affiliation is continued, so long as the tax advantage is given in the liquidation area. The basis in the stock will save the parent from the consequences with which Congress was concerned in the liquidation area only in the one circumstance illustrated. In all others, the parent will be subject to the same evil as the parent in the liquidation situation. ${ }^{101}$

The overall conclusion reached in this area thus would lead to a regulation providing that the basis of subsidiaries' assets be adjusted to the parents' basis in the subsidiaries' stock when a consolidated return is filed. ${ }^{102}$

\section{Reflection of Affiliates' Earnings and Profits in the Parent's Basis in the Stock}

Because of their bearing on the deferred accounting system, it will be useful to first consider the different ways in which the old

101 It might be argued that the two-year requirement of $\S 334(\mathrm{~b})(2)$ indicates that the step-up should only be available if the consolidated return is filed within two years of acquisition. However, the policy behind allowing the step-up seems to be the same even after two years. The parent has still paid an amount in excess of the basis of the assets and to give a carryover basis will cause a tax on a gain that is not the parent's. Moreover, when a parent which purchases a subsidiary's stock for $\$ 100$ receives a carryover basis of $\$ 50$ in the assets, it is treated worse than a taxpayer which is not a controlling corporation and receives the assets in a liquidation under $\$ 331$. Such a taxpayer would have no gain and would obtain a $\$ 100$ basis in the assets in the above case. Such an irrational distinction should not be written into the consolidated return regulations also. The fact that the appreciation is lost at the corporate level, and that one no longer has the liquidation parallel on which to fall back after two years, would be persuasive if the exemption from gain were not so firmly implanted in the liquidation area in situations indistinguishable on policy grounds from the instant problem. Also, it would be desirable to have some assurance that the old shareholders would bear the tax on the appreciation. Dependence on the market to discount the tax-which occurs if the group is taxed on a consolidated return by not giving a step-up-seems insufficient.

102 Since it appears that no loss should be carried over, even to separate income of the affiliate, there is no need to preserve the basis of the assets for any purpose. Therefore, a step-up or down to the basis of the stock would suffice. There would be no loss taken which the parent had not incurred (paid for) and no appreciation realized for which it paid. The market values of the assets for purposes of determining if there is a need for a step-up or down should be determined as of the time of acquisition of the stock necessary for affiliation. If this date is used, even if the filing of a consolidated return is delayed, there would be no losses the parent had not incurred or gains that the parent would not realize because it paid for the appreciation. If the date of consolidation were used, basis in assets which the parent paid for would be lost if markets had dropped. Using the acquisition date follows $\S 334$ (b) (2). Treas. Reg. §1.334-1(c) (4) (1955) should be followed for the handling of interim events. The new regulations do use the date of acquisition to determine built-in losses that are disallowed. Treas. Reg. $\$ \S 1.1502-15$ (a) (1), (a) (2) (1966). 
and new regulations reflect the profits and losses of the subsidiary in the parent's investment. The new regulations call for the basis of a subsidiary's stock in the parent's hands to be raised for increases and to be lowered for deficits in earnings and profits of the subsidiary. The old regulations and the original proposals for new regulations reduced the basis of the stock only for "losses availed of" by the group and never increased the basis. ${ }^{103}$

If the parent liquidates the subsidiary, operates it and later sells the assets or reincorporates the subsidiary and sells the stock, any profits or losses of the subsidiary will be reflected in the parent's basis in the assets or the stock. ${ }^{104}$ For example, suppose a parent purchases the stock of a subsidiary for $\$ 1000$ and liquidates it. Suppose further that, in five years, the division representing the subsidiary earns $\$ 500$ after taxes, thereby increasing its net assets by $\$ 500$. If the parent then sells these assets for $\$ 1500$, there will be no gain to the parent, since its basis will be $\$ 1500$. One would obtain the same result after a section 351 reincorporation of the subsidiary. Even without a consolidated return, a subsidiary with earnings and profits could distribute them tax free and thus avoid any tax at sale on these earnings and profits. ${ }^{105}$ As has been previously pointed out, if an increase in basis is not given, the entity will pay taxes on this income twice. The entity paid tax on the income when it was earned and it will now pay tax at the capital gains rate on the remainder after taxes. The only argument for allowing a double tax is that there is such a double tax at the corporate level if separate returns are filed. This probably occurs, however, because the normal situation where a capital gains tax would obtain and be appropriate occurs when an individual holds the stock. In such a case, there would not be a double tax at the corporate level. The complete exemption of dividends at the corporate level when the surtax exemption is waived, as it is when a consolidated return is filed, indicates that a double tax is felt to be inappropriate, at least where the corporations are under common

103 The difference in language between reducing the basis for "losses availed of" by the parent which could not have been used by the subsidiary (in the old regulations), and the provision for reduction of the full loss (in the final proposals) is less significant than it seems. It is mainly the result of the decision to increase the basis for income in the final regulations. The result on disposition would seem to be the same if the basis is increased and decreased to reflect the full net profits and losses of the subsidiary, or if the basis is reduced only by the "losses availed of" by the parent that the subsidiary could not have utilized, but increased by the net profit of the subsidiary, after reducing that profit by the losses of the subsidiary carried over to that income. There is a difference, however, if there is a minority interest, since the "Iosses availed of" provision reduced the basis by the full amount the parent used to offset income, while the new regulations only reduce the basis by the percentage of the loss corresponding to the parent's ownership in the subsidiary. See note 107 infra and accompanying text.

104 The basis of the stock would be the basis of the assets contributed.

105 INT. REv. CODE of 1954, $\$ 243$ (a) (3), 301 (c) (1), (c) (2). 
control. ${ }^{106}$ Although the double tax is permitted, despite the inconsistency, when separate returns are filed, this can be viewed as the price of the election to be treated as separate entities. When a consolidated return is filed, the theory being to treat the entity as one, the double tax is inappropriate. The same argument and theory indicate that there should be a reduction in basis for the amount of any loss sustained by the subsidiary.

The final regulations provide for the increase in basis of the parent's stock to be by the same percentage of the subsidiary's income as the parent owns of the subsidiary's stock. If the parent purchases 80 per cent of the stock of a subsidiary for $\$ 800$ and the subsidiary then has after tax profits of $\$ 100$, to $\$ 80$ of which the parent has a right and on which it bore the tax, it seems proper to raise the basis of the stock by only $\$ 80 .^{107}$

The situation with losses, however, involves different considerations. As with the income, the parent incurs a loss of its subsidiary only to the extent of its interest in the subsidiary. This indicates that the basis of the stock of the subsidiary owned by the parent should be reduced by an amount corresponding to the percentage of the subsidiary owned by the parent, as the regulations provide. It also indicates that only that percentage of the loss should be allowed to offset the parent's profits. Complete offset, however, has always been allowed by the regulations, ${ }^{108}$ and by accounting practice. ${ }^{109}$ Furthermore, the legislative history seems to assume complete offset. ${ }^{110}$ On the other hand, it would be both possible and in line with the historic

106 The 100 per cent dividend exclusion is permitted only to groups that meet the affiliation requirement for consolidated returns under $\$ 1504$. See INT. REV. CoDE of $1954, \S \S 243$ (a), (b) (1), (b) (5).

107 Treas. Reg. $\$ 1.1502-33$ (c) (4) (1966). The prior versions of this regulation called for an adjustment reflecting all of the subsidiary's increment or deficit in earnings and profits. See, e.g., Proposed Treas. Reg. (II) $\$ 1.1502-33$ (c) (4), 31 Fed. Reg. 16700 (1966). That provision was probably motivated by a desire for ease of administration.

108 See, e.g., Treas. Reg. $\S \S 1.1502-31 \mathrm{~A}$ (a) (1), (a) (5) (1955).

109 See, e.g., R. Wixon, Accountants' HandBook $\$ 23$, at 45 (4th ed. 1956).

110 See S. REP. No. 960, 70th Cong., 1st Sess. 13-15 (1928). It has been such a basic part of the consolidated return that continued re-enactment of the consolidated return provisions after such a long history of complete offset would seem to prevent regulatory amendment without specific congressional authorization.

There is also a mechanical problem caused by incomplete offset. For example, if a subsidiary had a $\$ 100$ profit and a parent owning 80 per cent of the subsidiary had a $\$ 100$ loss of which $\$ 80$ could be used to offset the subsidiary's profit, the parent would share 80 per cent of the tax on the $\$ 20$, although the parent had no profit. Segregation of the profit to the minority seems unadministrable.

Administrative difficulty also stands in the way of partial offset when the parent has the profit and the subsidiary the loss. For example, suppose the subsidiary has a $\$ 100$ loss and the 80 per cent parent a $\$ 100$ profit and only $\$ 80$ of the loss is permitted to offset the parent's profit. The remaining $\$ 20$ loss would be available as a carryover to the subsidiary's future profit. Yet, the 80 per cent parent would naturally obtain the benefit of 80 per cent of the remaining loss via the carryover, thus obtaining the use of 96 per cent of the loss when it only incurred 80 per cent of the loss. Any attempt to prevent this result would require an impossible segre- 
position of the regulations to reduce the basis of the subsidiary's stock held by the parent by the full amount of the loss, rather than by the parent's proportionate share of the loss. The regulations have always required a reduction in the basis of the subsidiary's stock for the full amount of the subsidiary's "losses availed of" by the parent, even if there were a minority interest in the subsidiary. ${ }^{111}$ Reduction of basis by the full loss utilized would prevent the profit of the parent from being completely exempted from tax through the offsetting of loss which the parent did not incur against the parent's income. Thus, if the parent bought 80 per cent of the subsidiary for $\$ 80$ and the subsidiary had a $\$ 10$ loss which offset $\$ 10$ of the parent's income, later sale of the subsidiary's stock for its reduced value of $\$ 72$ would result in a $\$ 12$ gain. The problem with this solution is that, if a complete offset is felt to be proper in the first instance, there seems to be no theoretical justification for taxing the profits at disaffiliation. ${ }^{112}$ The fact that the old regulations did so by the "losses availed of" rule is insufficient justification. It was never necessary to do so, given the stated purpose of that rule. The provision was intended to prevent double deduction of losses. ${ }^{113}$ This would not have happened if only the parent's share of the losses had reduced basis. Without the provision, if a parent buys 80 per cent of a subsidiary for $\$ 80$ and the subsidiary then has a $\$ 10$ loss which the parent deducts after which the stock is sold for $\$ 72$, there will be a second $\$ 8$ loss. However, only an $\$ 8$ or 80 per cent reduction is necessary to avoid the second $\$ 8$ loss.

There is one major problem with the new regulations in this area. If, instead of selling the subsidiary's stock, the parent and

gation of the loss between minority and parent or the complete disallowance of the remaining loss as a carryover, depriving the minority of its rightful offset. Disallowance of the carryover seems a theoretically sensible solution to prevent escaped income, since the minority does not obtain its use with full offset in any case. However, it must be noted that, since partial offset is not a possible solution when the parent has the loss, there would be partial offset only if the subsidiary has the loss. Such a solution might unfairly discriminate against the parent. When the parent has the loss, it will pay tax on income it does not have because the parent will lose the right to carry forward against its future income the portion of the loss offset against the minority's profit. Yet, when the subsidiary has a loss, the parent cannot recoup the tax incurred on behalf of the minority by utilizing the minority's loss.

111 See, e.g., Treas. Reg. \$1.1502-35A (1955).

112 The administrative difficulties of partial offset also militate against reduction of basis as a solution. If the subsidiary has a $\$ 100$ profit and the 80 per cent parent has a $\$ 100$ loss which is completely offset, reduction of the minority shareholder's basis for the proportionate share of unincurred loss utilized is not feasible.

If the subsidiary has a $\$ 100$ loss and the parent uses it to offset $\$ 100$ of its profit, a reduction of basis by $\$ 100$ to catch the escaped income has no advantage over a system of partial offset of the loss coupled with disallowance of the carryover of the remainder, as suggested in note 110 supra. In addition, such a procedure has the disadvantage of discriminating between those who sell their stock and those who do not.

113 See PEEx, supra note 21, § 8.04, at 104. 
subsidiary begin to file separate returns because the sale of stock leaves the parent with less than 80 per cent of the stock, the regulations call for adjustments provided for during consolidation to be reversed to the extent that increases in basis exceed decreases. ${ }^{114}$ This means that, if there is a separate return filed by the subsidiary after consolidation, a major portion of the advantages described are lost ${ }^{115}$ to the proportionate extent that stock in the subsidiary is still owned by the parent. If there had been a liquidation and reincorporation, there would be no such loss of benefit. After reincorporation, the basis of the stock would remain the same as it was at the time of reincorporation. There seems to be no reason why disaffiliation should be treated differently. This provision in the final regulations is a departure from the proposed version ${ }^{116}$ and appears to be a backward step.

\section{Distributions}

If the conclusions above are accepted, it follows that the basis of the subsidiary's stock should be reduced for all distributions to the parent. Since the post-affiliation earnings and profits were considered an increase in the investment, any return of them is a return of investment. Were this not done, a fictitious loss would result. Returns of capital in the traditional sense naturally should reduce the basis.

The only problem that exists in this area concerns distributions out of pre-affiliation earnings and profits. These too, as has been stated, are obviousiy returns of capital, but they are not treated as such outside the consolidated return area, even when dividends are excluded from income. ${ }^{117}$ However, if the parent liquidates the subsidiary and removes assets from the division representing the subsidiary to the extent of pre-acquisition earnings and profits, the basis of the assets in the division will be reduced. If the division is then reincorporated and sold, the basis of the stock sold will be this reduced basis. ${ }^{118}$ The result when separate returns are filed might be distinguished and rationalized as a cartyover from the usual shareholder situation in which the shareholder is an individual and an investor and is taxed on the distribution, thus warranting no reduction in basis. Given this rationale, there seems to be no need to follow it

114 Treas. Reg. §1.1502-32(g) (1966).

115 The only advantage not lost is where, for example, a subsidiary with a basis of $\$ 1000$ to the parent has losses in years one through five of $\$ 100$ per year and a $\$ 500$ profit in year six. The basis of the stock would be $\$ 1000$ and this would not change because of disaffiliation. The basis of the stock would have been $\$ 900$ under the old "losses availed of" provision. This provision did not reduce basis for losses which the subsidiary could have utilized against separate income without a consolidated return.

116 Proposed Treas. Reg. (II) § 1.1502-32(c), 31 Fed. Reg. 16698 (1966).

117 INT. REv. CODE of 1954, §§ 301 (c), 316.

118 Pre-acquisition earnings and profits would be eliminated in a $\$ 334$ (b) (2) liquidation under $\$ \S 381$ (a) (1), (c) (2) of the 1954 Code. 
when the theory of the return views the stockholder and corporation as one. In fact, even if this were not the explanation for the rule on separate returns, its carryover does not seem required, given the theory of the consolidated return. As stated earlier, in granting the benefits of being treated as one corporation, there is no compulsion to continue all the benefits which separate entities enjoy.

If, in making adjustments because of losses of the subsidiary or because of distributions, the basis of the stock reaches zero, there seems to be no reason not to have an excess loss account or negative basis. For example, assume a liquidated subsidiary with a basis of $\$ 100$ which, through losses or depreciation and distribution, depletes the net basis of the assets below zero, so that there is a debit value of $\$ 50$ for the net worth on a tax balance sheet. If the parent then sells the assets for $\$ 50$, there will be a $\$ 100$ gain recognized. ${ }^{119}$ There is no justification for treating the situation any differently on the consolidated return. There is certainly no justification for treating any excess as a present gain when the entity has actually realized no gain as did both the old regulations ${ }^{120}$ and proposals. ${ }^{121}$ The final regulations, except as noted below, use an excess loss account. ${ }^{122}$

Before considering the areas in which an excess loss account is not employed, it is necessary to consider a problem involving the manner in which the regulations recognize the excess loss account. So long as affiliation continues and consolidated returns are filed, the excess loss account is "taken into account" as each share of stock is sold. However, where either the subsidiary or the parent ceases to be a member of the group, either because of insufficient stock ownership or the filing of separate returns by election, the entire account is recognized. ${ }^{123}$ Reductions of the basis of the stock before the need for the excess loss account arises are normally not realized until ultimate sale. ${ }^{124}$ The excess loss account, containing the same adjustments as are made in the stock, is indistinguishable from that situation and should be treated in the same manner. If there had been a liquidation and later reincorporation, there would be a gain recognized to the extent that the liability exceeded the basis of the assets on reincorporation, which would be the case in situations where the excess loss account arises. However, this appears to be necessary because there is generally no provision for a negative basis, and, absent this, taxation of the gain will otherwise be lost. Since

119 See INT. REv. CoDE of 1954, §§ 351, 357; See also Parker v. Delaney, 186 F.2d 455 (1st Cir. 1950), cert. denied, 341 U.S. 926 (1951). The negative book value would have to arise from liabilities in excess of the basis of the assets.

120 Rev. Rul. 201, 1957-1 CuM. BuLc. 295.

121 Proposed Treas. Reg. (I) \$1.1502-14(2), 30 Fed. Reg. 12574 (1965).

122 Treas. Reg. §1.1502-19 (1966).

123 See note 73 supra and accompanying text.

124 Treas. Reg. $\$ \S 1.1502-32$ (a), (j) (1966). 
the excess loss account preserves the gain for taxation, there is no need for immediate recognition.

The regulations continue to tax distributions of cash in excess of basis when there is a liquidation not within section $332 . .^{125}$ However, since the filing of a consolidated return can be viewed as a joining together, as in a section 332 liquidation, there would appear to be no occasion for taxation upon a liquidation occurring after the filing of a consolidated return. Since there is gain recognized to the distributor in a section 332 liquidation, utilizing section 334 (b) (2), to the extent of section 1245 and section 1250 income when there is a step-up, it seems that there should be such a gain recognized on a section 334 (b) (2) liquidation of an affiliate which has been filing a consolidated return. The regulations provide for such recognition. ${ }^{126}$ In fact, if the basis of the assets is stepped-up to the parent's basis in the stock of the subsidiary at the time a consolidated return is first filed, as was advocated above, this section 1245 and section 1250 income should be recognized and taxed at that time.

\section{Intercompany Profit and Loss}

The new regulations attempt to solve the Beck Builders problem by providing a deferred accounting system for intercompany sales, ${ }^{127}$ instead of adapting the "dividend" method discussed earlier to the new provisions regarding reflection of income, loss and distributions in the basis of the stock of the subsidiary. Such an adaptation of the "dividend" method has been proposed and called the "book value" method. ${ }^{128}$ In order to evaluate the deferred accounting system, it will be helpful to compare the results under the two systems. For the time being, the section $312(\mathrm{j})$ problem raised earlier will be put aside, since neither proposal, as will be seen, seems to solve it completely. It will be assumed that any loans are not government loans.

Suppose that a parent has a basis of $\$ 1000$ in the stock of a subsidiary and sells to the subsidiary for $\$ 200$ an asset having a $\$ 100$ basis to the parent. The "book value" method calls for the subsidiary to take a carryover basis of $\$ 100$ in the asset and for the basis of the stock in the parent's hands to be reduced by $\$ 100$. This reduction is made regardless of the existence of earnings and profits in the subsidiary because all distributions reduce the basis of the stock in the parent's hands under the new regulations, in order to reflect the reduction in the net book value of the subsidiary. If the asset is sold outside the group for $\$ 200$, the $\$ 100$ gain is recognized by the subsidiary on the consolidated return. The basis of the stock in the subsidiary is

125 See note 74 supra and accompanying text.

126 Treas. Reg. § 1.1502-14(c) (2) (1966).

127 See notes 61-65 supra and accompanying text.

128 See Note, 78 Harv. L. REv. 1415 (1965). 
increased to recognize the increase in the net basis of the subsidiary's assets. If the subsidiary is then sold for $\$ 1000$, assuming that there have been no other changes, there will be no gain at that time. This is the same result which the deferred accounting system yields, except that the gain under the deferred accounting system is recognized to the parent rather than to the subsidiary. Since the group has a gain from the outside, there is no dispute that the group should be taxed. In both cases the gain takes its character from the asset sold, ${ }^{129}$ although the deferred accounting system terminates the holding period at the time of sale within the group, ${ }^{130}$ while the "book value" method tacks the holding periods.

If, in the above example, the subsidiary is sold outside the group, the parent will recognize a $\$ 100$ gain under the "book value" method and under the regulations. Under the "book value" method, however, the purchaser receives a corporation with a basis of $\$ 100$ in the acquired asset, whereas, under the deferred accounting system, there is a $\$ 200$ basis. Thus, a second gain is recognized under the "book value" method if no step-up can be obtained under section 334(b) (2). In return, under the "book value" method, the original gain to the parent takes its character from the stock as an adjustment of basis, while the regulations provide for the single gain recognized therein to take its character from the asset sold in the intercompany transaction. ${ }^{\mathbf{1 3 1}}$

If, instead of the parent selling the subsidiary an asset, the subsidiary, in the above example, sells the parent the asset with a $\$ 100$ basis for $\$ 200$, the parent will receive a carry-over basis. The basis of the stock in the subsidiary will be increased by $\$ 100$ to reflect the $\$ 100$ net contribution under the "book value" method. If the asset is sold outside the group for $\$ 200$, the $\$ 100$ gain will be recognized by the parent. The same result is obtained under the regulations, except that the parent will recognize the gain under the "book value" method while the subsidiary will recognize the gain under the regulations. In addition, the difference in holding period rules is again applicable. If, however, the stock of the subsidiary is sold before the parent sells the asset, the "book value" method will recognize no gain. The gain will be recognized by the parent through depreciation or sale of the asset, using a carryover basis. On the other hand, the regulations will recognize a gain of $\$ 100$ to the subsidiary at the time of disaffiliation. The parent originally will have obtained a cost basis in the asset. The basis of the stock will be increased at the time of sale to reflect the profit of the subsidiary; as a result, no additional gain will be recognized.

Thus, both the "book value" method and the deferred accounting

129 Treas. Reg. \$1.1502-13(c) (4) (1966).

130 Treas. Reg. $\$ 1.1502-13$ (g) (1966).

131 Treas. Reg. $\S 1.1502-13$ (c) (4) (1966). 
system solve the basic problem raised by Beck Builders, with the section 312(j) exception mentioned earlier. ${ }^{132}$ The crucial differences between the systems are the timing of the gain, by whom the gain is recognized and whether one gain or two gains of different character should be imposed as a result of the intercompany transaction.

Both the "book value" and "dividend" methods employ the traditional tax mechanism for deferral of gain when control is retained over the transferred property. This mechanism calls for a substitute basis for the property received in the exchange, a carryover basis for the property transferred and results in two taxes on the same appreciation if the asset transferred retains its value. This is the method provided in section 351 . Under section 351, if an asset with a basis of $\$ 100$ and a fair market value of $\$ 200$ is contributed to a controlled corporation, the basis of the stock becomes $\$ 100$ and a carryover basis is given to the asset. In return for the deferral of gain on the exchange of stock for property, capital gain will be recognized on the sale of the stock if the asset holds its value. A gain also will be recognized to the corporation any time the asset is depreciated or sold. In addition to utilizing this traditional mechanism, the "book value" method has the advantage of not differentiating between contributions and distributions, on the one hand, and sales between parties not at arm's length, on the other hand. Both are treated as contributions and distributions. As a result of the above, the "book value" method treats the group exactly as it would be treated if there had been a section 332 liquidation followed by operation, interdivisional sales and a reincorporation and sale of the division representing the subsidiary. For example. if $P$ buys $S$ for $\$ 1000$, having $\$ 1000$ basis in its assets, liquidates $S_{\text {, }}^{133}$ sells a $\$ 50$ basis asset to the division representing $S$ for $\$ 100$ and then reincorporates the division, the basis of the subsidiary's assets will be $\$ 950$ - the basis of the assets transferred to the corporation. ${ }^{134}$ The subsidiary will have the asset transferred to it prior to reincorporation with a $\$ 50$ basis. This is the same result as outlined above following consolidated returns under the "book value" method.

The Treasury, however, chose the deferred accounting system rather than the "book value" method. The main motivation evidently

132 Although it might, at first glance, appear that the deferred accounting system taxes in the one situation where there was no problem, i.e., where there are post-affiliation earnings and profits, this is not, in fact, the case. For example, suppose $P$ buys $S$ for $\$ 1000 ; S$ has a $\$ 100$ profit; $P$ sells an asset to $S$ for $\$ 200$, at a profit of $\$ 100$; then $P$ sells $S$ for the fair market value of the assets, $\$ 1100$. Because the basis of the stock was raised to $\$ 1100$ to reflect the profit, there will be no tax on the sale of the stock, but deferred gain of $\$ 100$ will be "taken into account" at that time. Meanwhile, a tax was already paid by the economic unit on the $\$ 100$ earnings of $S$. Thus, a tax on a total of $\$ 200$ will be paid. The parent has increased the basis of its assets by $\$ 200$ as a result of having owned the subsidiary. This result seems proper and is the same as that reached prior to the new regulations. See notes $25-26$ supra and accompanying text.

133 Under $\S 332$ of the 1954 Code.

184 INT. REv. CODE of 1954, $\S \S 351,358,362$. 
was a desire to apportion income between the affiliates so that it was recognized to the affiliate which "earned it." 135 This was considered important primarily because it was felt necessary to have accurate separate incomes for the various times that separate incomes are relevant under the regulations. Examples are: 1 ) the Western Hemisphere deduction, based on the separate income of each affiliate; ${ }^{136} 2$ ) the regulations permitting pre-affiliation loss carryovers to be carried to the separate income of the subsidiary; ${ }^{137}$ and 3 ) apportionment of the tax burden between affiliates, determined by separate income. Under both the "book value" method and the old regulations, if $P$ sold $S$ an asset with a basis of $\$ 50$ and a fair market value of $\$ 100$ for $\$ 100$ in year one, followed by a sale outside the group for $\$ 100$ in year two, $S$ would recognize the $\$ 100$ gain in year two on the consolidated return. Thus, for all of the above purposes, the $\$ 50$ gain attributable to $P$ would be shown in the separate income of $S .{ }^{138}$ The deferred accounting system solves both this problem and the Beck Builders problem.

This justification, however, is not wholly satisfactory. Putting aside for a moment the tax apportionment example, the underlying justification for the items for which separate income is needed is not entirely clear. For instance, assuming no minority interest, it is not clear why the Western Hemisphere deduction should be determined for the separate income of each affiliate rather than for the group as a whole, given the theory of consolidated returns. ${ }^{139}$ It is also unclear why a pre-acquisition loss carryover should be allowed at all if a section 332 liquidation under section 334 (b) (2) would result in a loss of the carryover. Even if there had been no purchase and a section 332 liquidation would result in a section $334(\mathrm{~b})(1)$ liquidation, the carryover of a loss would be determined under section 381 and section $382(\mathrm{~b})$ and the separate income of the division representing the subsidiary would be irrelevant. However, such provisions as the loss carryover and Western Hemisphere deduction by separate income may remain entrenched in the consolidated return because, it is not politically feasible to eliminate them. ${ }^{140}$ Is this need for an

135 Salem, The Consolidated Return Regulation Revision: Its Genesis and Objectives, 17 TAX EXeCuTIVE 163 (1965).

Mr. Salem became Technical Assistant to the Chief Counsel, Internal Revenue Service on March 30, 1964. Prior to that time, he was a member of the Office of the Tax Legislative Council of the Treasury Department. He has now returned to private practice.

138 Treas. Reg. $\$ 1.1502-25$ (1966).

137 Treas. Reg. $\$ \$ 1.1502-21$ (c), (d), (e) (1966).

138 See note 82 supra.

139 Since $\$ 1503$ of the 1954 Code seems to assume that there will be separate determination of Western Hemisphere qualification for each affiliate, this contention is somewhat academic.

140 In the case of the Western Hemisphere deduction, there appears to be a congressional assumption of separate determination for each affiliate, which would require the regulations to call for separate determination and accurate reflection of separate incomes. 
"accurate separate income" a sufficiently persuasive reason for having a deferred accounting system?

There are two objections. First, the need for an accurate determination of separate income in one area does not necessarily mean that the system for determining the taxation of intercompany profits need be the same. Separate records could be kept for each purpose. Second, if the subsidiary is 100 per cent owned by the parent, it is difficult to understand why it is an "accurate" reflection of income, for the purposes described, to have the intercompany profit reported by the member which sold first rather than to have it reported by the member which sold it outside the group. In other words, what in substance distinguishes, for these purposes, a contribution-distribution and an intercompany sale? If $P$ contributed an asset worth $\$ 100$ to $S$, which had a basis of $\$ 50$ in the asset, and $S$ distributed $\$ 100$ to $P$, followed by a sale outside the group, the income would be in $S$ 's separate income for the purposes mentioned.

The first of these criticisms is not too persuasive. There are three factors which favor the use of the deferred accounting system: (1) the administrative difficulty of two systems; (2) the fact that the system, although usually using the "book value"-section 351 deferral route, seems to have no policy objection to recognition of the income on the sale of the asset and a step-up; and (3) the fact that one of the advantages of section 351-type treatment-administrative ease-is defeated. The second criticism is more persuasive, but it should be remembered that section 482 is available to help draw a rational distinction between intercompany sales at a profit and contributiondistributions. ${ }^{141}$

More important, there is an additional-and on policy grounds, far more persuasive-reason for favoring the deferred accounting system, a reason which was evidently not an important factor in its adoption. This is the effect of the existence of a minority interest in the subsidiary. For example, assume that the "book value" method is used and the parent sells a $\$ 100$ basis asset to the subsidiary for $\$ 200$, with the subsidiary selling or depreciating the asset. The parent's shares in the subsidiary are then sold, with a sale of the asset subsequent to that sale. The minority interest in the subsidiary will lose its interest in the $\$ 200$ basis assets which were given up and will obtain an interest in only $\$ 100$. It thus will lose its share of $\$ 100$ of basis, although its corporation paid cost for the asset. As a result, it will bear a tax, when the subsidiary sells the asset, on a $\$ 100$ gain which it never realized. The minority interest is taxed on profits which the parent obtained. Moreover, if the asset which the parent

141 This would control in situations where the asset had built-in appreciation at the time of the intercompany transfer by the parent and the parent received the benefit of the appreciation via a property distribution from the subsidiary. This is in contrast to the normal contribution and distribution, in which there is no reason to believe that the asset has built-in appreciation realized by the parent. 
sold to the subsidiary is sold outside the group by the subsidiary before disaffiliation, the parent will bear only 80 per cent of the tax on the profit, assuming 80 per cent ownership; yet, it will obtain the benefit of all the gain. This would not occur in the liquidation situations, where there is no continuing minority interest limited to an interest in the subsidiary's assets. Recognition of this gain to the subsidiary also means that the earnings and profits of the subsidiary are increased by this gain and that the minority pays tax on distributions therefrom, even though these distributions are in fact returns of capital to the minority, since the outlined transactions did not increase the basis of the assets in which the miniority shares.

If, instead of the parent selling to the subsidiary, the subsidiary sells to the parent at a $\$ 100$ profit, the minority will bear no tax on this gain under the "book value" method, despite the fact that the basis of their share of the subsidiary's assets will increase. If there is a distribution from the profit, there will be no tax on the distribution as a dividend, because earnings and profits are not increased to reflect the gain. The parent, however, with a carryover basis in the asset, although no better off than before the transactions, will bear a tax on the $\$ 100$ through lower depreciation deductions or sale. Assuming a $\$ 200$ sale price and $\$ 100$ basis to the subsidiary before sale, the parent will have given up $\$ 200$ in assets for the $\$ 100$ basis asset obtained. Although it still owns 80 per cent of the assets given up, the parent will have lost $\$ 20$, representing the minority's gain. The shareholders of the parents will bear a dividend tax on distributions from this $\$ 20$, even though it represents no gain to them. By deferring recognition to the original selling member and giving the original buying member a stepped-up basis, the deferred accounting system overcomes all of these inequities.

This concern for the problems created by the minority interest was alluded to by those concerned with drafting the regulations. ${ }^{142}$ The concern for proper apportionment of tax between affiliates mentioned earlier has relevance only with regard to the need for proper treatment of the minority and controlling interests caused by the existence of a minority interest. However, the problems outlined above go beyond proper allocation of tax burden at the corporate level during affiliation. They go also to proper taxation after affiliation and proper taxation of distributions. In addition, the minority interest gives more weight to the concern about proper income determinations for pre-affiliation carryovers and Western Hemisphere deductions. If these are removed or improperly computed, the minority, although it bore the loss or owns part of a corporation which if separately owned would be entitled to a Western Hemisphere deduction, loses its injectives, 17 TAX EXecutTVE 163, 167 (1965). 
terest in these benefits. It is difficult to view the minority as part of one merged corporation because it has no interest in the profits of the parent, but is limited to a share in the profits and losses of the subsidiary. These factors, in conjunction with the factors more directly motivating the drafters, to the degree they were found persuasive, lead to the conclusion that the deferred accounting system is preferable to the "book value" method.

Although recognition of the minority interest aspect of consolidated returns has not been emphasized in the law or literature, ${ }^{143}$ there is ample support for giving it greater consideration. The House Report, in recommending the consolidated return provisions in the 1954 Code, emphasized the importance of proper apportionment of the tax burden among affiliates, because of the expanded degree to which minority interests were involved in consolidated returns under the 1954 Code. ${ }^{144}$ The concern for tax apportionment is a recognition and concern for the minority interest. Financial accounting practice, a natural touchstone for giving content to the concept of a consolidated return, recognizes the interest of the minority. There is strict and careful concern for proper reflection of the minority interest's share in consolidated balance sheets and income statements. ${ }^{145}$ More significant, one recognized method for reflecting consolidated income eliminates only that portion of intercompany profit which represents the common ownership of the affiliates. In other words, if $S$, a subsidiary of which 80 per cent is owned by the parent, sells an asset to the parent at a $\$ 100$ profit, only $\$ 80$ of the profit is eliminated and $\$ 20$ is recognized as part of consolidated income, attributable to the minority interests. ${ }^{146}$ Finally, a system very close to the deferred accounting system is used in financial accounting. ${ }^{147}$ Separate statements and records of separate income are kept as if the entities were not

143 But see Western Pac. R.R. Corp. v. Western Pac. R.R. Co., 206 F.2d 495 (9th Cir.), 345 U.S. 247 (1953), 216 F.2d 513 (9th Cir. 1954); Case v. New York Cent. R.R., 19 App. Div. 2d 383, 243 N.Y.S.2d 620 (1963); B. BitTkER \& J. Eustice, Federal Income Taxation of Corporations and Shareholders 692 (2d ed. 1966) ; Johnson, Minority Shareholders in Affiliated and Related Corporations, 23 N.Y.U. TAX INST. 321 (1965); 112 U. PA. L. Rev. 1185 (1964).

144 H. Rep. No. 1337, 83d Cong., 2d Sess. 88 (1954).

145 See, e.g., W. KarRenbrock \& H. Simons, supra note 68 , at 301-578.

146 H. Finney \& H. Miller, Principles of Accounting-Advanced 376-88 (5th ed. 1961); R. Wixon, Accountants' HANDBOOR \$23, at 50 (4th ed. 1956). This is based on the theory outlined above-the subsidiary's minority interest has immediately realized a gain to the extent of its ownership of the subsidiary. For some unsatisfactorily explained reason, accounting principles do not apply the same theory to sales of assets by the parent to the subsidiary, although there seems to be as much reason to do so as in the case of sales by the subsidiary to the parent. The system of immediate recognition would not function well for tax purposes because of the difficulties of segregation. For instance, suppose an 80 per cent owned subsidiary sells an asset to $P$ at a $\$ 100$ profit, and only $\$ 80$ of the profit is eliminated. There would be a tax on $\$ 20$. It appears unadministrable to have a system in which the tax is segregated to be borne by the minority alone.

147 W. KARRENBRock \& H. Simons, supra note 68 , at 409-28, 519-59. The formal deferred profit system need not be used since, for reporting purposes, the gain can be recognized immediately on the individual records and statements of affiliates. 
affiliated. Profits on intercompany sales are reflected and assets are kept at the cost basis of the individual affiliates on these records. These are the records to be used for deciding any state law questions and these are the records which will follow the affiliates after disaffiliation-no adjustments are ever made to the basis of stock to reflect intercompany profits. Besides protecting the minority, this indicates that any administrative fears of the impracticability of the deferred accounting system are unfounded.

In addition to the justifications mentioned above, it should be noted that any recognition being given to the minority interest factor here is not in the form of direct recognition, such as partial elimination or partial offset of profits and losses, but rather as a factor in choosing between two systems designed to solve another problem. This factor, along with those mentioned as motivating the Treasury, supply reasons for not using the normal deferral mechanism of the Code. The normal mechanism appears to be based on a desire for easy administrability, which is not gained in this instance, rather than on any other policy.

Finally, any problem of distinguishing between contributions coupled with distributions and sales is greatly reduced if there is a minority. The parent will have a state law responsibility to deal with the subsidiary at arm's length and to use fair market values for intercompany sales. In addition, if a contribution and distribution is made, the minority interest problems cease to exist, since the minority will share in both the distribution and the contribution. For example, if $P$ contributes a $\$ 100$ basis asset to the subsidiary of which it owns 80 per cent and the subsidiary distributes $\$ 200$, the minority interest will be entitled to $\$ 40$ of that distribution. Therefore it has regained its lost basis via distribution, and will not be unfairly dealt with if it bears a tax on its $\$ 20$ share of profit on the asset at sale. In fact, it is $\$ 20$ ahead, since it recovered $\$ 40$ and also received a $\$ 20$ share of basis in the asset contributed by the parent, the contribution being shared by all. Thus, the evils which lead to a preference for the deferred accounting system do not exist if there is a contribution and distribution.

There remains one technical problem specifically related to the deferred accounting system. The regulations provide that there shall be no tacking of the holding period of the asset. ${ }^{148}$ However, since at least 80 per cent common ownership bears the risk on the asset the entire time that it is held, it would appear that tacking is warranted. The 20 per cent minority will receive a windfall if the asset goes from $P$ to $S$. But, since the alternative is imposing an unwarranted ordinary

The consolidated financial statements are temporary statements which eliminate the profit, but never appear on the individual corporate records in any way. There is no elimination on the permanent records. Thus, after affiliation has terminated, the individual corporations need make no adjustments on their records.

148 Treas. Reg. $\S 1.1502-13$ (g) (1966). 
tax on 80 per cent versus giving 20 per cent a windfall, it would seem that the 80 per cent should be favored.

It remains to be seen whether the factual problem in Beck Builders, i.e., the government loan problem caused by section $312(j)$, which the "book value" method did not solve, ${ }^{149}$ is solved by the new regulations. Consider the hypothetical case once again: $P$ buys $S$ for $\$ 1000 ; P$ then builds a building for $\$ 50$ which it sells to $S$ for $\$ 100$; $S$ obtains a government-insured loan for $\$ 100$ secured by the building, which it uses to pay $S$; $S$ is sold for $\$ 1000$, since the loan offsets the market value of the building. The parent has $\$ 50$ on which neither it nor the group has paid tax. The deferred accounting system taxes the $\$ 50$ of deferred gain at the time of sale. Therefore, if the transaction is in the form of a sale, the regulations do solve the Beck Builders problem because, in the absence of a distribution, section $312(j)$ is technically inapplicable. However, this solution is not completely satisfactory, because the policy of section $312(\mathrm{j})$ is defeated. If prior to sale of the asset or the stock of the subsidiary, the parent distributes the $\$ 50$ in realized appreciation, the parent's shareholders will not be taxed on a dividend distribution, even though the distribution is ultimately derived from realization of appreciation on an asset via a government loan. If the two corporations had been one and an interdivisional shift of assets corresponding to the sale had occurred, with the corporation obtaining a government loan secured by the asset in the amount of the asset's value, followed by a distribution to the corporation's shareholders of the excess of loan over basis, the distribution would be a taxable dividend. The corporation's earnings and profits would have been increased immediately before the distribution under section $312(j)$. If the regulations are followed, this result is avoided.

There is, moreover, a much more vital defect with the regulations when there is a government loan in excess of the basis of the security. If, instead of the parent constructing the building, the subsidiary constructs the building for $\$ 50$, obtains a $\$ 100$ government loan secured by the building and distributes the $\$ 50$ excess, the new regulations allow the gain to escape tax at sale. Under section $312(\mathrm{j})$, the earnings and profits of $S$ are increased immediately before distribution. As a result, the regulations call for the basis of $S$ 's stock in $P$ 's hands to be increased to $\$ 1050$. After distribution, the regulations provide for a $\$ 50$ reduction in basis to $\$ 1000$. If the stock is then sold for the $\$ 1000$ fair market value of the net assets, there will be no gain at sale. As a result, the parent has $\$ 50$ in tax free income. The Beck Builders problem has not been solved if there is a government-insured loan.

A regulation providing that section $312(j)$ does not apply to consolidated returns is not a wholly satisfactory solution. Just as in the transaction framed as a sale discussed above, if section $312(\mathrm{j})$ 
is inapplicable, the later distribution of the $\$ 50$ by $P$ to its shareholders will not be taxed as a dividend, provided that $P$ has no earnings and profits of its own. Thus, a distribution to shareholders from appreciation realized through a government-insured loan will be received tax free at the shareholder level, contrary to the intent of Congress as expressed in section $312(\mathrm{j})$.

There is a solution which will accomplish both objectiveseliminating the Beck Builders loophole and taxing the shareholders of the parent. This solution would provide that: (1) the subsidiary's earnings and profits would increase by the excess of any government loan over the basis of its security immediately before any distribution by the subsidiary; (2) neither the earnings and profits of the parent nor its basis in the subsidiary's stock would increase to reflect the increase described in (1); (3) the distribution to the parent from earnings and profits of the subsidiary created by section $312(j)$ would not result in any increase in the parent's earnings and profits, but the basis of the stock would decrease as in any other distribution; (4) immediately before the parent made any distribution, it would increase its earnings and profits for its proportionate ownership in any government loan which it or any affiliate owes, to the extent the loan is in excess of the basis of the security given for the loan. As a result, if the subsidiary in the above example constructs the building for $\$ 50$, borrows $\$ 100$ and distributes $\$ 50$ to its parent, the $\$ 50$ will result in a net decrease of $\$ 50$ in the basis of the subsidiary's stock to $\$ 950$. Thus, when the stock is sold for its fair market value of $\$ 1000$, there will be a $\$ 50$ taxable gain to $P$, closing the Beck Builders loophole. Yet, if the parent distributes $\$ 50$, having no earnings and profits of its own, there will be a taxable distribution to its shareholders because the parent's earnings and profits will be increased by the $\$ 50$ excess of the government loan over the basis of its security immediately before distribution. This satisfies the policy behind section $312(j)$. If the transaction had been framed as a sale of a $\$ 50$ basis asset to the subsidiary for $\$ 100$, with a $\$ 100$ government loan to the subsidiary, the desired ends also would be achieved. If the subsidiary were sold for the $\$ 1000$ fair market value of its assets, there would be a $\$ 50$ deferred gain taken into account, preventing any income from escaping tax. If there were a $\$ 50$ distribution by the parent while it retained the subsidiary and the asset, the parent's earnings and profits would be increased immediately, preceding the distribution of the appreciation realized through the loan, causing the distribution to be taxed as a dividend to that extent. Again the policy behind section $312(\mathrm{j})$ would be satisfied. These results correspond to those obtaining if the affiliates were one corporation. ${ }^{150}$ $\S 312(j)$. For example, suppose a subsidiary borrows $\$ 100$ on a government loan 
It is true that on the later sale of the asset for $\$ 100$ in the contribution-distribution example, earnings and profits again would be increased at the corporate level for the same appreciation, and any distribution would result in a second dividend on the $\$ 50$ to any shareholders. Similarly, when the transaction is framed as a sale, earnings and profits will be increased once again for the $\$ 50$ appreciation when the deferred profit is taken into account. However, a second increase always appears to be the result under section $312(\mathrm{j})$ and is not peculiar to consolidated returns. ${ }^{\mathbf{1 5 1}}$

\section{Earnings and Profits}

There remain to be considered the various regulations with regard to earnings and profits, other than those determining which affiliates should reflect intercompany profits in their earnings and profits.

In the proposed regulations, the corollary to the finally adopted regulations' reflection of earnings and profits of the subsidiary in the basis of stock in the parent's hands was the reflection of the fluctuation in the parent's earnings and profits. If a subsidiary had postaffiliation earnings and profits and the parent, having no separate earnings and profits of its own, distributed property to its shareholders, the result under this proposal would have been to tax the shareholders on receipt of a dividend. Having accepted treatment of the two companies as one, this seems proper. In addition, the parent's power over the earnings and profits would make any other result turn completely on form.

secured by a $\$ 50$ asset. The subsidiary makes no distribution to the parent in any form, but the parent, having no earnings and profits, makes a distribution to its shareholders. Under the regulations, this distribution will not be taxable as a dividend to the parent's shareholders yet, the parent has complete control over the appreciation realized outside the group.

If the two corporations were one, the earnings and profits would be increased immediately before the distribution, and the shareholders would be taxed on the distribution. There is no reason for different consequences when a consolidated return is filed.

151 For example, suppose a corporation borrows $\$ 100$ on a $\$ 50$ basis asset and then distributes the $\$ 50$ appreciation. Under $\$ 312(\mathrm{j})$ there will be a dividend and a tax. If the asset is later sold for $\$ 100$, there will be a $\$ 50$ gain. If a distribution follows, there will be a second $\$ 50$ dividend, since no provision is made for tracing.

In addition to the second increase in earnings and profits for the appreciation described, there will be an increase in earnings and profits in the transaction framed as a contribution-distribution, when the stock is sold to reflect the $\$ 50$ gain on the sale of the stock. However, this is a function of the imposition of two taxes at the corporate level on the same appreciation when the deferral method utilized in the contribution-distribution area is used. This same result would occur even if $\$ 312(\mathrm{j})$ were inapplicable.

Moreover, if the two corporations were one; interdivisional transfers of assets corresponding to the contribution-distribution took place, with a similar government loan; a distribution of the excess of loan over basis was made to the shareholders; and reincorporation and sale of the division including the appreciated asset with the subsidiary adopting the liability followed, there would be three increases in earnings and profits for essentially the same appreciation, just as is provided in the proposed system. 
However, the final version of the new regulations holds this decision in abeyance. For one year it is made optional. ${ }^{152}$ If the option to use the system outlined above is not taken, the earnings and profits are not increased or decreased until the increment or deficit in the subsidiary's earnings and profits is realized through sale of the subsidiary's stock or distribution by the subsidiary. For the reasons given above, it is advisable that the original proposal be carried through and the adjustment made.

There is one other major problem with the regulations' treatment of earnings and profits. Both the first draft of the proposed regulations and the finally adopted regulations continue to increase the parent's earnings and profits for pre-affiliation earnings and profits of the subsidiary at the time they are distributed. ${ }^{153}$ This means that the shareholders will be taxed on distributions from such increment in earnings and profits. If there were a stock purchase followed by liquidation, the shareholders would not be taxed on distributions out of that division's pre-liquidation earnings and profits. The only justification for different treatment on the consolidated return is that distributions out of pre-affiliation earnings and profits are always returns of capital, yet are always taxed to the shareholders. However, treatment as one corporation under the consolidated return seems to be sufficient justification for treating the shareholders as shareholders of the liquidated corporation. This is particularly true in light of the demonstration above, that distributions to the parent should be treated as a return of capital which reduces its basis in a subsidiary's stock.

\section{Characterization}

It has been previously noted that a corollary to the deferred accounting system is the derivation of the character of the deferred gain from the asset sold in the intercompany sale. ${ }^{154}$ There are additional problems of characterization worthy of note.

The first of these is how gains, to the extent of adjustments made to the stock for distributions and losses, should be characterized. By making the adjustments to the stock, the regulations, at first glance, seem to treat such gains like all gains from the sale of the stock, usually a capital asset. This certainly appears proper for distributions since they represent a return of capital. However, the losses offset ordinary income. In Merchants National Bank v. Commissioner, ${ }^{155}$ the court of appeals for the Fifth Circuit held that gain on the sale of

152 Treas. Reg. $\$ 1.1502-33$ (c) (4) (ii) (1966).

153 Proposed Treas. Reg. (II) \$1.1502-14(b) (2), 31 Fed. Reg. 16694 (1966); Treas. Reg. 1.1502-14(b) (2) (1966). See also Treas. Reg. \$1.1502-37A (a) (1) (i) (1955); Proposed Treas. Reg. (I) $\$ 1.1502-14$ (b) (2), 30 Fed. Reg. 12574 (1965). 154 See text accompanying notes 124-27 supra.

155199 F.2d 657 (5th Cir. 1952) ; accord, First Nat'l Bark of Lawrence County, 16 T.C. 147 (1951). 
a note previously written off as worthless would be ordinary rather than capital gain, although the note was a capital asset, because the prior loss had offset ordinary income. This case arguably could be extended judicially to the reduction for losses. There is an implication that the regulations assume Merchants to be inapplicable to the adjustments to the stock, since they make special provision for ordinary gain with respect to the excess loss account, ${ }^{156}$ but otherwise make no mention of the problem. If there had been a liquidation, and losses by the division representing the subsidiary followed by reincorporation of the subsidiary, the basis of the stock would not include losses and it seems unlikely that the gain to the extent of the losses would be other than capital, if the stock were a capital asset. ${ }^{157}$ The situation under consideration seems indistinguishable. Furthermore, if ordinary income is obtained and the bases of the assets of the subsidiary are not stepped-up, there will be two gains at ordinary rates on the same appreciation. This result is never found in the Code if the asset is held for the capital gains period. ${ }^{158}$ Finally, there is not the potential for trading ordinary loss for capital gain that existed in the Merchants case. For these reasons, that decision's rationale is inapposite. It should be noted that the Merchants case has not been extended to situations where the asset had not been written down to zero.

Although not mentioning the Merchants problem when the basis of the stock is involved, the regulations do provide that, if the subsidiary is insolvent, the excess loss account should be recognized as ordinary income to the extent that it was created by losses of a subsidiary, unless the losses creating it can be shown to have offset capital gains. ${ }^{159}$ This is apparently done in reliance on the Merchants rationale. In all

156 Treas. Reg. $\$ 1.1502-19$ (a) (2) (ii) (1966).

157 There is a possibility that this reincorporated division would be a collapsible corporation, because any appreciated assets contributed might be contributed with a view to selling the stock before a substantial part of the appreciation is realized, assuming immediate sale of the stock. This fact, however, takes away none of the force of the comparison made to justify capital gains treatment. The reasons for collapsible treatment are to prevent unrelated dangers generally not existing in the case of continued separate incorporation. Where the dangers do exist, the subsidiary, in the example, would also be considered a collapsible corporation. Section 341 provides for ordinary income treatment for the reincorporated division because of the potential for utilizing a corporation to avoid both ordinary income and double tax treatment by contributing appreciated assets to the corporation, with the purchaser liquidating the corporation tax free.

This potential for avoidance does not exist where the corporations are already separate and no appreciated assets are obtained with a view to selling the stock before a substantial part of the appreciation is realized. If appreciated assets were obtained with such a purpose in mind, the subsidiary, in the example, would be a collapsible corporation irrespective and independent of the considerations in the text. Collapsible treatment has no relation to losses deducted from ordinary income, to insolvency or to a negative basis. In addition, a three-year interval before sale of the stock or a $\S 341$ (f) election would avoid ordinary income treatment.

158 Even where $\$ 341$ is applicable, see note 157 supra, a $\$ 341(f)$ election avoids double taxation at ordinary rates.

159 Treas. Reg. $\$ 1.1502-19$ (a) (2) (ii) (1966). 
other situations the excess loss account takes its character from the stock. Apparently, insolvency was used as a touchstone, because of the worthlessness of the note in Merchants and the insolvency of the borrower in analogous cases. The excess loss account is made up of the same elements and has the same characteristics as the stock and the adjustments to the stock. Different treatment appears unreasonable. The provision is even less defensible if the same rule is not applied where there is no excess loss account, the subsidiary is insolvent and the basis of the stock has been written down to zero.

\section{ConCLUSTON}

The new regulations have taken a major step forward in their treatment of intercompany transactions and stockholdings. The most significant of these steps are: (1) the adoption of the deferred accounting system; ${ }^{160}$ (2) provisions for the reflection of changes in a subsidiary's earnings and profits in the parent's basis in the subsidiary's stock; ${ }^{101}$ and (3) provisions for an excess loss account if distributions or losses of a subsidiary exceed the parent's investment in the subsidiary. ${ }^{162}$ However, the regulations have failed to go far enough in some respects and, in addition, have undercut their own steps forward. Certain loopholes also exist in the new regulations.

While the regulations prevent built-in losses of an affiliate from offsetting the income of other affiliates, they permit the parent to be taxed on appreciation in assets accruing prior to acquisition of the subsidiary. ${ }^{163}$ In addition, pre-acquisition built-in losses are permitted to offset the subsidiary's income, although the situation is fraught with opportunity for the parent to transfer income to the subsidiary in order to utilize the loss-yet, no loss would be allowed if there were a conceptually parallel liquidation. ${ }^{164}$ This defect could be remedied by a provision requiring the basis of a subsidiary's assets to be adjusted to the basis of the parent's stock in the subsidiary, if the parent's share in the basis of the assets exceeded its basis in its stock.

The regulations have undercut the provisions requiring adjustments to the basis of the parent's stock in the subsidiary to reflect changes in the subsidiary's earnings and profits by reversing these adjustments when positive adjustments exceed negative adjustments, if affiliation is terminated before all of the stock is sold. This means that there will be two taxes on the same income paid by the same entity at the corporate level, although this would not be the result if there had originally been one corporation followed by a divisive reorganization

160 See notes 61-66 supra and accompanying text.

101 See notes 67, 128-48 supra and accompanying text.

162 See note 72 sipra and accompanying text.

163 See notes 98-101 supra and accompanying text.

164 See note 92 supra and accompanying text. 
creating a parent-subsidiary relationship. This is one of the least defensible provisions.

While the adjustments to the basis of the stock are made for the changes in earnings and profits of the subsidiary, a decision on whether the earnings and profits of the parent also should be changed to reflect the changes in the subsidiary's earnings and profits was postponed for one year. If such an adjustment is not made, the parent's shareholders will pay no tax on distributions when the parent has complete control over the earnings and profits accruing to itself. This result is artificial ${ }^{16 \overline{5}}$ and contrary to the result if the two corporations were one. Consequently, it should be provided that, as of January 1, 1968, the earnings and profits of a parent shall reflect its share of any changes in the subsidiary's earnings and profits.

The regulations also provide that earnings and profits of the parent should be increased if there are distributions from pre-affiliation earnings and profits by the subsidiary. This will cause taxation to the shareholders of the parent if there is a subsequent distribution to them. If there were a section 334(b)(2) liquidation instead of consolidated filing, pre-affiliation earnings and profits of the subsidiary would be eliminated Therefore, a distribution to the parent's shareholders from what used to be pre-affiliation earnings and profits would not result in a dividend. The consolidated return is the same conceptually-and should provide the same result. ${ }^{166}$

The excess loss account should be recognized proportionately as the stock is sold, not in total at disaffiliation, as the regulations provide. It contains the same adjustments as are made to the stock and recognition should be treated in a parallel manner. ${ }^{167}$ Also, the excess loss account should derive its character, for capital gains purposes, from the stock, even when the subsidiary is insolvent, contrary to the new regulations. There seems to be no relevant difference between an insolvent subsidiary with a positive basis in its stock and one with a negative basis. Nor should the fact that losses have reduced ordinary income matter, since it would not be a relevant factor if there were a divisive reorganization after losses.

Finally, and perhaps most important, the regulations should be adjusted to accomodate section $312(\mathrm{j})$, thereby preventing avoidance of tax through the Beck Builders-type device. The current regulations allow the Beck Builders loophole if there is a government loan in excess of the basis of its security to a subsidiary followed by a distribution; yet, section $312(j)$ is defeated on a normal intercompany sale if there

165 See note 152 supra and accompanying text. 106 See note 153 supra and accompanying text.

167 See note 123 supra and accompanying text.

168 See notes $155-59$ supra and accompanying text. 
is a government loan in excess of the basis of its security by the subsidiary. ${ }^{169}$ This most crucial problem could be solved by a regulation providing that: (1) the subsidiary's earnings and profits would increase by the excess of any government loan over the basis of its security immediately before any distribution by the subsidiary; (2) neither the earnings and profits of the parent nor its basis in the subsidiary's stock would increase to reflect the increase described in (1); (3) the distribution to the parent from earnings and profits of the subsidiary created by section $312(j)$ would not result in any increase in the parent's earnings and profits, but the basis of the stock would decrease as in any other distribution; and (4) immediately before the parent made any distribution, it would increase its earnings and profits for its proportionate ownership in any government loan it or any affiliate owes, to the extent it is in excess of the basis of the security given for the loan. These four provisions would prevent any tax free distributions out of realization of appreciation through loans, and would prevent any tax free realization of income. ${ }^{170}$

169 See notes 149-51 supra and accompanying text.

170 This conclusion is a summary of the major suggestions for revision made in the body of this Comment-it is not a summary of all the suggestions for revision made herein. 